\title{
Working
}

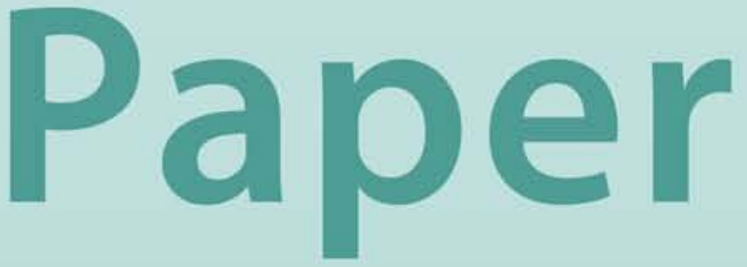


Do Remittances to Latin America Depend on the U.S. Business Cycle?

Shaun K. Roache and Ewa Gradzka 


\title{
IMF Working Paper
}

Western Hemisphere Department

\section{Do Remittances to Latin America Depend on the U.S. Business Cycle?}

\author{
Prepared by Shaun K. Roache and Ewa Gradzka ${ }^{1}$
}

Authorized for distribution by Dominique Desruelle

December 2007

\begin{abstract}
This Working Paper should not be reported as representing the views of the IMF. The views expressed in this Working Paper are those of the author(s) and do not necessarily represent those of the IMF or IMF policy. Working Papers describe research in progress by the author(s) and are published to elicit comments and to further debate.
\end{abstract}

We use a range of methods and remittance data from 1990 to 2007 to assess the strength and significance of linkages between remittance flows to Latin America and the U.S. business cycle. All of the evidence suggests that remittance flows are relatively insensitive to fluctuations in the U.S. cycle, underlining their role as a stable source of external financing, in good times and bad. A number of factors, notwithstanding uncertainties related to official remittance data reliability, might explain this result, including remittance smoothing and flexible immigrant labor markets.

JEL Classification Numbers: E32, F15, F16, F22, F24,

Keywords: Remittances, Business cycles, Latin America

Authors’ E-Mail Addresses: SRoache@imf.org, EGradzka@imf.org

\footnotetext{
${ }^{1}$ We would like to thank Jeromin Zettelmeyer, Roberto Garcia-Saltos, Steve Phillips, Hunter Monroe, Wendell Samuel, and seminar participants in the Western Hemisphere Department at the International Monetary Fund for guidance, comments, and suggestions.
} 


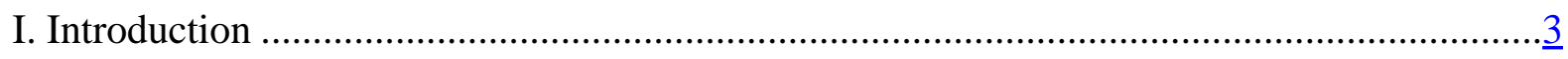

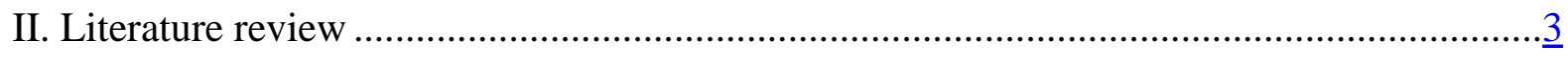

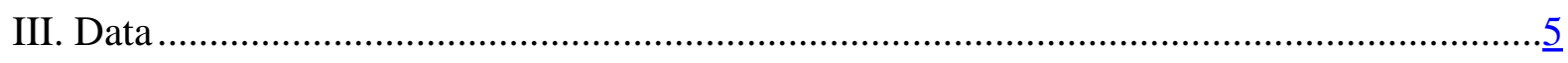

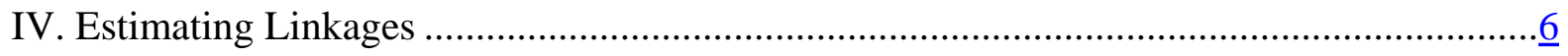

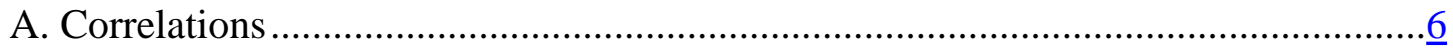

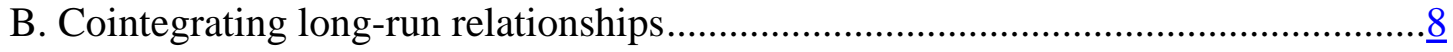

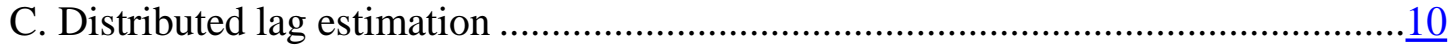

D. Dynamic factor model...........................................................................................

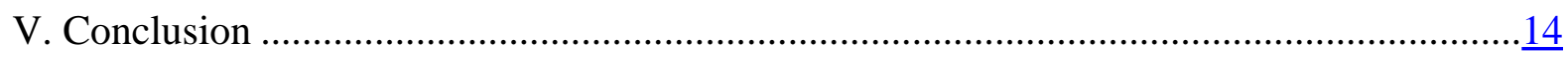

Tables

1. Summary Statistics for First-Differenced Remittance Data ....................................................

2. Dynamic Common Factor Model: Sensitivity of Remittances ............................................14

Figures

1. Remittance Flows to Latin America, 2006 ............................................................................

2. Correlations Between Sample Countries and U.S. Indicators ..............................................

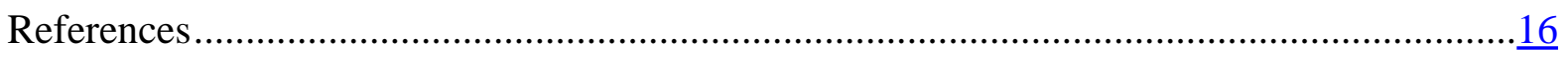

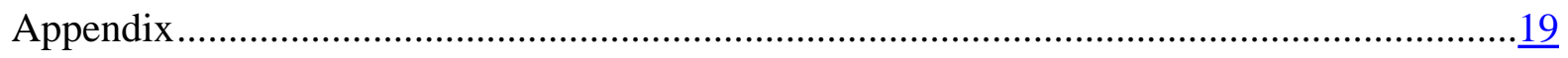




\section{INTRODUCTION}

Remittance flows sent by migrant workers to Latin America have grown rapidly in recent years and, for some countries, now account for a significant share of GDP and rival or even dwarf FDI as a source of external financing (Figure 1). Such trends have brought remittances to the forefront of the economic policy agenda and much attention has been given to how best to use this new source of finance in the recipient countries. With many economies in the region increasingly relying upon remittances for external finance, an important question to ask is: what are the factors that drive these remittance flows? Over the long-term, sociodemographic and institutional factors, in the host and recipient countries, are likely to have a dominant influence. However, in the short-term, might economic conditions in the host country influence these remittance flows?

In this paper, we assess the extent to which economic conditions in the United States- the most important host country for migrant workers from Latin America-influence remittance flows. A number of theoretical models that describe remittance behavior have been proposed — see Rapoport and Docquier (2005) for a survey—but little work has addressed the role that host country business cycles play. Without a strong theoretical foundation, our approach is deliberately empirical and does not test the predictions from any one particular theory. Instead, we subject to the data to broad and rigorous testing to assess if, and how much, U.S. economic conditions matter for remittances.

The plan for the remainder of the paper is as follows: section II provides a brief survey of the literature focusing on our main question; section III describes the data and the issues surrounding the measurement of remittances; section IV outlines the econometric procedures and their results; and section $\mathrm{V}$ provides concluding remarks.

\section{LITERATURE REVIEW}

The literature on the determinants of remittances has grown rapidly in recent years but, perhaps surprisingly, little has been written on the impact of host country economic conditions. The main areas of focus have been: the sociodemographic profile of migrants and families; macroeconomic, political, and other conditions (such as natural disasters) prevailing in the country of origin; transaction costs; and rate of return factors that may affect portfolio decisions. Of the work that has touched upon the linkages between host country cycles and remittance flows, few consistent and rigorous conclusions have emerged. 
Figure 1. Remittance Flows to Latin America, 2006 1/
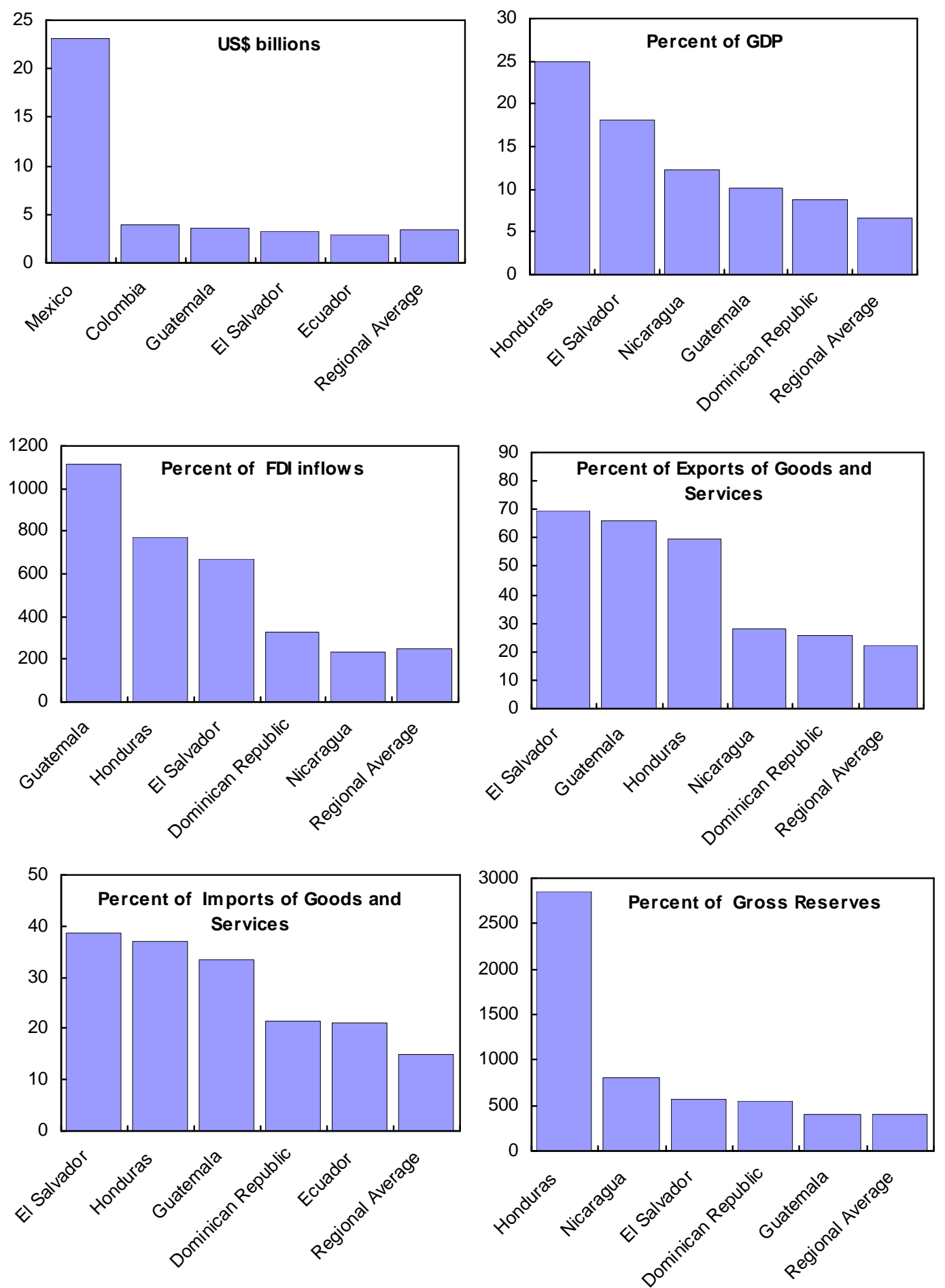

Source: National authorities.

1/ Each figure shows the top 5 ranked from the sample including the following countries: Argentina, Brazil, Colombia, Costa Rica, Dominican Republic, Ecuador, El Salvador, Guatemala, Honduras, Mexico, Nicaragua, Peru, Uruguay, Venezuela. The regional average is an unweighted mean. 
Vargas-Silva and Huang (2006), looked at flows from the U.S. to the rest of the world and Mexico, using quarterly data from 1981 to 2003 and found some evidence of linkages from the U.S., although it is far from conclusive. Using a vector error-correction model, only one U.S. indicator, inflation, was found to Granger causes remittance flows to the rest of the world. Home country conditions (proxied by economic indicators for the top five receiving economies) were also unimportant, which contrasts with many other results. For Mexico there was evidence of Granger causality of a range of U.S. indicators; however, wide standard deviations of impulse responses and variance decompositions make it difficult to pin down precisely these effects.

Lueth and Ruiz-Arranz (2006), apply a gravity model to 11 remittance-receiving countries in the Middle East, Europe, and Asia, and use bilateral remittance data. The level of remittance flows are regressed on income levels in home and host countries, the physical distance between the two countries and other effects, including per capita income growth as the measure of the state of the host country cycle. A positive, significant, yet small coefficient of 0.03 is found on per capita growth, although this effect disappears in slightly different specifications. Gupta (2005), estimates that cyclical remittances flows to India-measured using the Hodrick-Prescott filter - exhibit an elasticity to U.S. employment of 0.13 . With a standard deviation of total nonfarm payrolls — the U.S. variable used in the study—of less than 0.4 percent, this elasticity appears to be economically insignificant.

Lianos (1997), focuses on remittances to Greece and finds that host country income levels and the exchange rate are significant. El-Sakka and McNabb (1999), focused on remittance flows to Egypt and suggest that source country conditions were important, with a lag, albeit with a very low elasticity of around 0.03 . Sayan (2004), suggest, using data on remittances to Turkey from 1987-2001, that there is no statistically significant relationship between remittance flows to Turkey and the business cycle in Germany, a country that accounts for the largest share of migrant Turkish workers. Aydas, Metin-Ozcan, and Neyapti (2005), also focus on the Germany-Turkey link and find the opposite; however, their framework regresses remittance growth on host country income levels, leaving the interpretation, at least from a business cycle perspective, less than clear-cut.

\section{DATA}

Remittances are typically defined as that portion of a migrant worker's earnings sent back from the country of employment to the country of origin. While exact definitions and methods of measurement vary across countries, remittances have begun to be defined in a broader context; increasingly, the term "personal transfers," including "all current transfers in cash or in kind made, or received, by resident households to or from other non resident households” (United Nations, 2005) is being used to describe remittance flows.

The growth and scale of remittances have brought them to the forefront of the economic policy agenda, but accurately measuring these flows remains a challenge. Official data typically include only financial transfers made through formal channels, the costs of which 
have declined (e.g. Orozco, 2004, 2006); as a result, some portion of the surge in flows may be related to a diversion of existing flows. Remittances-in-kind, such as goods sent to homecountry households or payments made on behalf of these households, are usually not counted. There is also the possibility that official remittance data mistakenly captures other types of transfers, including from illegal activities (e.g. Gutiérrez, Romellón, and Vázques, 2006).

This paper uses quarterly remittance flow data from 1990 Q1 to 2007 Q2 as reported by national authorities and typically included in the balance of payments; i.e. flows that are recorded through formal channels. Table 1 presents an summary of the remittance data.

Table 1. Summary Statistics for First-Differenced Remittance Data, 1990 Q1 - 2007 Q2 1/

\begin{tabular}{|c|c|c|c|c|c|c|}
\hline & $\begin{array}{l}\text { Sample } \\
\text { size }\end{array}$ & Mean & Maximum & Minimum & $\begin{array}{l}\text { Standard } \\
\text { deviation }\end{array}$ & $\begin{array}{l}\text { Percent of variance } \\
\text { due to seasonality }\end{array}$ \\
\hline \multicolumn{7}{|l|}{ South America } \\
\hline Argentina & 52 & -0.5 & 34 & -34 & 14.0 & 85 \\
\hline Brazil & 49 & -0.4 & 39 & -30 & 14.2 & 14 \\
\hline Colombia & 44 & 3.7 & 29 & -28 & 11.4 & 27 \\
\hline Ecuador & 32 & 2.1 & 18 & -15 & 6.7 & 19 \\
\hline Mexico & 49 & 3.2 & 14 & -19 & 5.9 & 71 \\
\hline Peru & 68 & 4.2 & 30 & -25 & 7.2 & 48 \\
\hline Uruguay & 28 & 4.8 & 73 & -78 & 24.4 & 1 \\
\hline Venezuela & 40 & 2.9 & 51 & -42 & 17.4 & 35 \\
\hline \multicolumn{7}{|l|}{ Central America } \\
\hline Costa Rica & 19 & 3.7 & 19 & -20 & 10.1 & 18 \\
\hline El Salvador & 37 & 2.1 & 14 & -5 & 4.3 & 76 \\
\hline Guatemala & 53 & 4.6 & 78 & -20 & 15.5 & 11 \\
\hline Honduras & 17 & 6.7 & 13 & -2 & 4.3 & 47 \\
\hline Nicaragua & 28 & 2.6 & 14 & -21 & 6.3 & 12 \\
\hline Dominican Republic & 36 & 1.9 & 14 & -16 & 5.4 & 95 \\
\hline
\end{tabular}

Source: National authorities; authors' calculations.

1/ Seasonally adjusted first differences of log values in constant US dollars.

Before assessing linkages, the data were adjusted for seasonal effects (using the U.S. Census Bureau's X12 program) and deflated by the U.S. consumer price index, to ensure consistency with the typically seasonally adjusted and constant prices U.S. economic indicators. For most of the techniques applied in this paper, the data also need to be stationary, which in their loglevel form, they were not. Two separate methods were used: first-differencing and extracting the cyclical component from the Hodrick-Prescott filter.

\section{Estimating LinKAges}

\section{A. Correlations}

Correlations are a simple way to assess linkages between remittances and the U.S. business cycle. To ensure a wide coverage of possible relationships, two sets of correlations were produced. The first - as shown in Appendix Figures A2 and A3—-show the distribution of the 
correlations between a specified U.S. economic indicator and remittance flows across the sample of 14 countries. The second-as shown in Figures A4 and A5-show the distribution of correlations between a specified country and a range of 19 U.S. economic and financial indicators. These correlations use first-differenced data (similar results are obtained from correlations of HP-filtered data) and show the correlation contemporaneously and against 1 to 4 quarter lags of the U.S. indicators. Figure 2 below summarizes the results, showing the distribution and the details for Mexico and El Salvador, the country which turns out to exhibit the highest correlations with U.S. economic indicators in the sample. Similar results are obtained for housing market and financial indicators.

Figure 2. Correlations between Sample Countries and U.S. Indicators 1 /
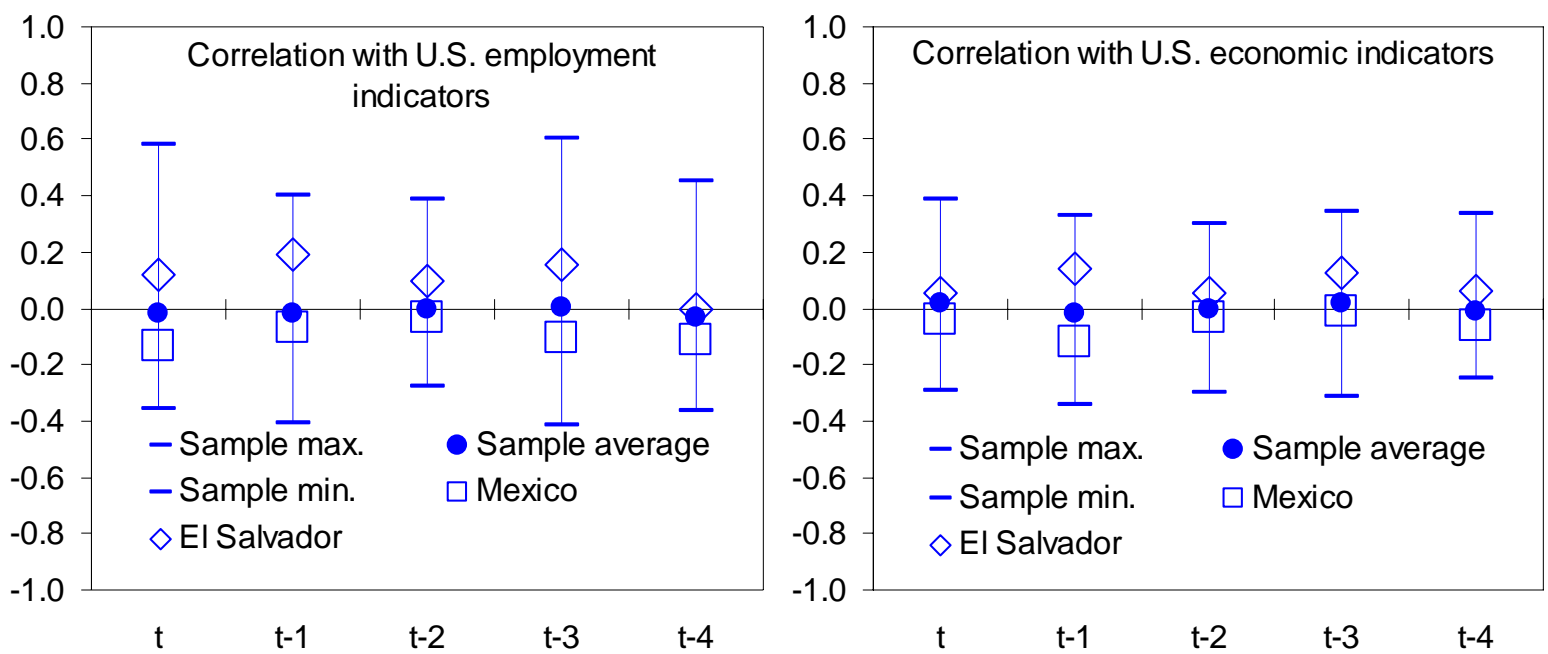

Source: Authors' calculations.

$1 /$ The highest (lowest) datapoint represents the maximum (minimum) average correlation between a particular country and the range of U.S. economic indicators.

The results are striking — simple correlations, averaged across countries and indicators, are close to zero. There is no one U.S. indicator that is strongly correlated across a set of country remittance flows and there is no one country for which remittances seem particularly sensitive to the U.S. economy. There are, of course, exceptions as shown by the extremes of the distribution, but these extremes typically are centered around zero; it is just as likely that one will find a strongly negative correlation between remittances to a country and a U.S. indicators as finding a strongly positive correlation. If it is difficult to provide any theory behind these "negative" results, it is difficult to attach too much weight to the positive extremes.

To emphasize the apparent randomness of the correlation results, Figure A6 in the Appendix highlights Mexico. The indicator with the highest correlation to remittances to Mexico in each period - contemporaneously and for up to 3 lags of the U.S. indicators - are shown. In all cases, these maximum correlations are neither large, nor statistically significant. Moreover, the correlations do not exhibit a pattern through time. For example, correlations 
do not appear to tail off after the peak, but rather continue to follow a random process around zero.

\section{B. Cointegrating long-run relationships}

At the aggregate level, there are a number of compelling theoretical and empirical reasons to suspect that there would be no long-run relationship between aggregate remittance flows to a particular country and the level of GDP (or other measure of income or activity) in the host country. A number of other factors, some of which are unobservable, could cause structural shocks to this relationship, including home country income, the earning potential and sociodemographic profile of migrants, the stock of migrants, and the average length of stay, among others. The short sample period also presents a challenge to the cointegration hypothesis, since it is difficult to identify long-run relationships with a maximum sample of just 17 years (and much less in most cases).

Some theoretical models clearly predict no stable, long-run bivariate relationship between remittance flows and the level of some host country economic indicator. For example, Funkhouser (1995), presents a model in which the altruistic motive for remittances is represented by the incorporation of the recipient's utility into the sender's utility function. A number of predictions emerge: emigrants with higher earning potential will tend to remit more; lower income in the sender country is associated with a higher marginal utility, and higher remittances; the relative importance of the recipient's utility in the migrant's utility depends on the type of relationship of the emigrant to the household member and any intention of return migration and; the amount that the emigrant sends is negatively related to the number of emigrants from the same home country household. All of these factors are subject to permanent change and would alter the relationship between remittances and host country income. Rapoport and Docquier (2005), provide an expansive survey of the theoretical literature and show that many of the prediction from the altruistic model are shared by the strategic motive model, an approach first described by Stark (1995).

Among the more relevant findings from the voluminous empirical microeconomic literature is that remittance flows per migrant tend to correlate negatively with the number of years spent in the host country (Funkhouser 1995, Lowell and De La Garza 2000, Rhyne 2007); this may be due to the relaxation of ties with the home country, the inheritance motive for dependents in the host country, and other factors. To maintain aggregate flows at a constant proportion of host country income would then require a replicating process in which new generations of migrants were of the same size and shared the same income-earning capacity and incentives to remit as their predecessors. While possible, it is likely that one or all of these variables will change over time.

Uncertainties related to the data should also encourage caution with regard to cointegration. For example, the reduction in transfer costs may have diverted existing remittance flows from informal to formal methods of transfer, causing a rise in the official estimates. Freund and Spatafora (2005), estimate that informal remittances amount to about 35-75 percent of official remittances to developing countries and that money transfer fees reduce the share of 
remittances transferred through the formal system and reported in national accounts. The stock of migrants may also have changed significantly, in part due to increasing flow of undocumented migrants. Assuming constant per capita migrant remittance flows, this would also induce a long-lasting change in the relationship between remittances and host country income. Both of these factors, transfer costs and the stock of migrants, are difficult to measure at the aggregate level and are typically not available as control variables in any long-run relationship.

We test for cointegration among two sets of variables: remittances and various U.S. economic indicators; and given the results from this stage, between remittances, U.S. GDP and home country GDP. The results from the Engle-Granger and Johansen procedures for bivariate cointegration are presented in the Appendix (Tables A2 and A3) and both indicate that GDP is the most likely candidate for a long-run relationship. However, with small samples system cointegration tests such as Johansen are often biased toward Type I errors - they often mistakenly reject the null hypothesis of no cointegration —and this bias increases in the lag length (e.g. Cheung and Lai, 1993). This is suggested by the results of the cointegration tests at varying lag lengths. In our analysis, we reject the null if the sample size is greater than 20 and the null is rejected at the 5 percent level by 2 out of 3 tests, using the appropriate lag lengths (Engle Granger, Johansen's trace and max-eigenvalue). ${ }^{2}$

Relatively stable long-run relationships between remittances and U.S. GDP are then found for three countries: Brazil, El Salvador, and Peru. Estimated impulse responses to a one standard deviation shock to U.S. real GDP-which amounts to a 0.5 percent change quarter on quarter-from vector error correction (VECM) models are presented in the Appendix. The results show that the long-run elasticity of remittances to U.S. GDP ranges from 1.9 (Peru) to 3.6 (El Salvador); note however that these estimates are sensitive to the lag length of the VECM and the effect often became weaker as more lags are added. ${ }^{3}$

Including home country GDP in the cointegration analysis allows the estimations to incorporate a factor that has been shown by many studies to be important for remittance flows. The results from the Johansen procedure are presented in the Appendix (Table A4) and show evidence of cointegration for the same three countries: Brazil, El Salvador, and Peru. Once again, the test results are sensitive to lag length, as shown in Appendix Table A5. Impulse responses and the long-run coefficient on U.S. GDP indicate that the positive effect of U.S. GDP on remittances disappears, with the cointegrating relationship appearing to pick up a common trend between the GDP series, not remittances. The normalized unit coefficients on remittances compares to much higher and statistically significant coefficients

\footnotetext{
${ }^{2}$ All cointegration tests and vector error correction models used the lag length selected by the sequential log likelihood ratio test, as presented in the Appendix.

${ }^{3}$ The results for Nicaragua and Uruguay were very sensitive to the lag length and did not converge, respectively, raising some doubts regarding robustness. Results for these two countries are not shown.
} 
on both GDP series and the short-run adjustment coefficient for remittances on the long-run relationship also became insignificant. ${ }^{4}$

In summary, the results indicate that remittance flows for very few countries show evidence of a stable long-run relationship with U.S. GDP (or other economic indicators). Where there is evidence of a long-run relationship, the results may be influenced by the small sample bias of system tests toward finding cointegration where none exists, while the resultant long-run elasticities are highly sensitive to changes in lag length and specification.

\section{Distributed lag estimation}

Assuming no long-run relationship between remittances and U.S. economic indicators, we move on to distributed lag estimation. This approach assumes that remittances are affected by the contemporaneous and lagged values of exogenous variables. In its most general form, this model would be written as:

$r_{i t}=\alpha_{i}+\sum_{s=0}^{P} \beta_{s} x_{t-s}+\sum_{s=0}^{R} \gamma_{s} z_{t-s}+e_{i t}$

where $r_{i t}$ is the quarterly percentage change in remittance flows to country $i$ in period $t, \alpha_{i}$ is a constant, $\beta_{s}$ is a sensitivity parameter to be estimated, and $x_{t-s}$ is a stationary measure of the U.S. business cycle in period $t-s$.

Control variables, denoted by $z_{t-s}$, may also be included and, given our focus on business cycles and the results from the literature, economic conditions in the home country appear to be the most appropriate. ${ }^{5}$ Other work has suggested that remittances tend to increase when conditions in the origin country deteriorate (e.g. Attzs and Samuel, 2007; and Yang and Choi, 2007). This may be due to country-specific issues, such as natural disasters, in which case the effects may be absorbed by the residual term (ignoring for now serial correlation and heteroscedasticity). However, if business cycle or economic growth indicators typically are correlated between the two countries, the omission of origin country regressors would imply serious specification errors. As a result, we have estimated the models with and without origin country GDP growth.

\footnotetext{
${ }^{4}$ Using the terminology of Stock and Watson (1988), the identification of one cointegrating vector implies the existence of two common trends in an three variable system. The model for Mexico suggests that both GDP series follow the same common trend, while the level of remittances follow a separate trend.

${ }^{5}$ It has been assumed that home country growth is exogenous to remittances. The literature has yet to determine whether growth in the short- or long-run is affected by remittances, and different conclusions have been drawn from mico and macro approaches. Giuliano and Ruiz-Arranz (2006), have shown that "the impact of remittances on growth is practically nil when the remittances variable is simply added as an additional explanatory variable in a standard growth model.”
} 
Lacking a compelling theoretical model—at least at the aggregate level—on which to base the specification necessarily leaves the model selection process relying upon measures of fit. Of course, this leaves us open to the charge of data mining but, given the current state of knowledge regarding remittances and business cycles, this is a defensible strategy. To provide some empirical structure on the estimation and conserve degrees of freedom, we use a polynomial distributed (Almon) lag approach, which imposes a smoothing constraint on the coefficients. For remittances to each country, a set of equations of varying lag order and polynomial order were estimated and those with the lowest Aikaike information criteria were selected for comparison.

Again, the results are striking since they provide no clear evidence of linkages between remittances and U.S. economic indicators-see Appendix Table A6. One way to see this is with the sum of the coefficients on the U.S. indicator and home country GDP growth, which should be interpreted as the long-run elasticity of remittance flows to an innovation in either variable. There were very few long-run coefficients that were significant at the 5 percent level, joint tests of the hypothesis all coefficients in each equation were significantly different from zero could not be rejected in most cases, and R-squares were typically low.

\section{Dynamic factor model}

The final method of estimation utilizes the dynamic factor model, which provides two benefits, as well described by Croux, Renault, and Werker (2004). First, it reduces the dimension of our model, allowing us to exploit both the cross section and time series nature of our entire dataset without having to estimate a large number of parameters from a relatively short sample. Second, it allows us to measure a quantity-the U.S. business cycle — that itself is not directly measurable through latent, or unobservable, factors.

The application of the dynamic factor/ state-space approach here is standard. A set of observed variables—including remittances and U.S. business cycle indicators—are assumed to be linear functions of a set of unobserved "state variables," or common factors. Such common factors often have a simple interpretation, depending upon the specification of the model, and this is described in detail in the next section.

We will briefly describe the set-up of the model. It is assumed that the dynamics of the ( $n \mathrm{x}$ 1) vector of observed variables $\mathbf{y}_{t}$-remittances and U.S. economic indicators-is a linear function of an unobserved ( $r \times 1)$ vector of state variables $\xi_{t}$ which follows an AR(1) process. This is written as:

$\mathbf{y}_{t}=\mathbf{A}^{\prime} \boldsymbol{\xi}_{t}+\mathbf{u}_{t}$

$\boldsymbol{\xi}_{t+1}=\boldsymbol{\Theta} \boldsymbol{\xi}_{t}+\mathbf{v}_{t+1}$

where $\mathbf{A}$ and $\boldsymbol{\Theta}$ are $(n \times r)$ and $(r \times r)$ matrices of parameters to be estimated, and $\mathbf{u}_{t}$ and $\mathbf{v}_{\boldsymbol{t}}$ are $(n \times 1)$ and $(r \times 1)$ vectors of white noise disturbances: 


$$
\begin{array}{ll}
E\left(\mathbf{u}_{t} \mathbf{u}_{\tau}^{\prime}\right)=\mathbf{\Sigma} & \text { for } t=\tau \\
E\left(\mathbf{u}_{t} \mathbf{u}_{\tau}^{\prime}\right)=\mathbf{0} & \text { for } t \neq \tau \\
E\left(\mathbf{v}_{t} \mathbf{v}_{\tau}^{\prime}\right)=\mathbf{\Omega} & \text { for } t=\tau \\
E\left(\mathbf{v}_{t} \mathbf{v}_{\tau}^{\prime}\right)=\mathbf{0} & \text { for } t \neq \tau
\end{array}
$$

The disturbances are also assumed to be independent across all lags:

$E\left(\mathbf{u}_{t} \mathbf{v}_{\tau}^{\prime}\right)=\mathbf{0} \quad$ for all $t$ and $\tau$

The common assumption is that $\xi_{1}$ and the sequence of disturbances $\left\{\mathbf{u}_{t}, \mathbf{v}_{t}\right\}$ for $t=1, \ldots, T$ are multivariate Gaussian, which implies that the distribution of the observable vector $\mathbf{y}_{\boldsymbol{t}}$ conditional on its lags $\mathbf{H}_{t} \equiv\left(\mathbf{y}_{t-1}, \ldots \mathbf{y}_{1}\right)$ is also Gaussian, with a likelihood function:

$$
f_{Y_{t} \mid H_{t}}\left(\mathbf{y}_{t} \mid \mathbf{H}_{t}\right)=(2 \pi)^{-\frac{n}{2}}\left|\boldsymbol{\Theta}^{\prime} \mathbf{P}_{t \mid t-1} \boldsymbol{\Theta}\right|^{-\frac{1}{2}} \times \exp \left\{-\frac{1}{2}\left(\mathbf{y}_{t}-\boldsymbol{\Theta}^{\prime} \xi_{t}\right)^{\prime}\left(\boldsymbol{\Theta}^{\prime} \mathbf{P}_{t \mid t-1} \boldsymbol{\Theta}+\boldsymbol{\Omega}\right)^{-1}\left(\mathbf{y}_{t}-\boldsymbol{\Theta}^{\prime} \xi_{t}\right)\right\}
$$

for all $t=1, \ldots, T$ and where the ( $r \times r) \mathbf{P}_{t \mid t-1}$ is the mean squared error matrix:

$$
\mathbf{P}_{t \mid t-1}=E\left[\left(\xi_{t}-\xi_{t \mid t-1}\right)\left(\xi_{t}-\xi_{t \mid t-1}\right)^{\prime}\right]
$$

The model is specified so that the observable vector is affected by the contemporaneous and lagged business cycle factor, and one remittance specific factor. Expanding the state equation (3), this structure may be written as:

$$
\left[\begin{array}{c}
\xi_{0 t} \\
\xi_{1 t} \\
\xi_{1 t-1} \\
\xi_{2 t}
\end{array}\right]=\left[\begin{array}{cccc}
1 & 0 & 0 & 0 \\
0 & \theta_{1} & 0 & 0 \\
0 & 1 & 0 & 0 \\
0 & 0 & 0 & \theta_{2}
\end{array}\right] \cdot\left[\begin{array}{c}
\xi_{0 t-1} \\
\xi_{1 t-1} \\
\xi_{1 t-2} \\
\xi_{2 t-1}
\end{array}\right]+\left[\begin{array}{c}
0 \\
v_{1 t} \\
0 \\
v_{2 t}
\end{array}\right]
$$

For any one remittance variable, this allows us to identify the source of variance in each period as a function of factor loadings (measures of sensitivity to the factors, denoted by $a$ ), the unobservable factors (denoted by $\xi$ ), and idiosyncratic shocks (denoted by $u$ ). To see this, we write the equation for remittances in country $i$ in period $t$ as:

$y_{i t}=\xi_{0}+a_{i 1} \xi_{1 t}+a_{i 2} \xi_{1 t-1}+a_{i 3} \xi_{1 t}+u_{i t}$

Substituting in the factor structure described above obtains:

$y_{i t}=\xi_{0}+a_{i 1}\left(\theta_{1} \xi_{1 t-1}+v_{1 t}\right)+a_{i 2} \xi_{1 t-1}+a_{i 3} \xi_{2 t}+u_{i t}$ 
Rearranging obtains:

$y_{i t}=\xi_{0}+a_{i 1} v_{1 t}+\left(a_{i 2}+a_{i 1} \theta_{1}\right) \xi_{1 t-1}+a_{i 3} \xi_{2 t}+u_{i t}$

From this structure we can obtain the two parameters of interest. First, the sensitivity to common business cycle innovations in period $t$, denoted by $a_{i 1}$, and secondly the factor's persistence $\theta_{1}$.

This model was estimated using first-differenced and HP-filtered data for 6 countries with data stretching at least as far back as 1995; exceptions were El Salvador and the Dominican Republic, which only start in 1998, but for which remittances are a large share of GDP. The set of observed variables was completed by including the following U.S. economic indicators: housing starts, GDP, construction employment, and services employment.

The results indicate weak, or nonexistent, linkages between remittances and the U.S. indicators over the sample period. In Table 2 below, the more positive the coefficientsthe $a$ 's from equation (10) - the more sensitive are remittances to the U.S. cycle; in most cases, the coefficients for remittance flows are not significant. However, the U.S. indicators show significant sensitivity to a common cycle (with the exception of Housing Starts, which is not shown). In the Appendix (Table A7), joint restrictions on the coefficients are tested, again suggesting that the U.S. cycle has little influence on remittance behavior. The possible exception, according to this analysis, are remittances to Mexico, which appear to share some similarities with a broad measure of the U.S. economic cycle; indeed, recent data for Mexico continue to suggest an emerging linkage. 
Table 2. Dynamic Common Factor Model: Sensitivity of Remittances $1 /$

\begin{tabular}{|c|c|c|c|c|c|c|c|c|c|}
\hline \multirow[b]{2}{*}{ Factor } & \multirow[b]{2}{*}{ Argentina } & \multirow[b]{2}{*}{ Brazil } & \multirow{2}{*}{$\begin{array}{c}\text { Dominican } \\
\text { Republic }\end{array}$} & \multirow{2}{*}{$\begin{array}{c}\text { El } \\
\text { Salvador } \\
\end{array}$} & \multirow{2}{*}{ Guatemala } & \multirow[b]{2}{*}{ Mexico } & \multirow{2}{*}{$\begin{array}{l}\text { U.S. } \\
\text { GDP }\end{array}$} & \multicolumn{2}{|c|}{ U.S. employment in: } \\
\hline & & & & & & & & construction & services \\
\hline \multicolumn{10}{|c|}{ First-differences model - estimated factor loadings } \\
\hline US cycle & $\begin{array}{c}0.08 \\
{[0.53]}\end{array}$ & $\begin{array}{l}-0.24 \\
{[0.72]}\end{array}$ & $\begin{array}{c}0.42 \\
{[0.38]}\end{array}$ & $\begin{array}{c}0.03 \\
{[0.54]}\end{array}$ & $\begin{array}{c}0.15 \\
{[0.43]}\end{array}$ & $\begin{array}{c}0.51 \\
{[0.62]}\end{array}$ & $\begin{array}{l}0.30 * * \\
{[0.12]}\end{array}$ & $\begin{array}{c}0.36^{\star \star *} \\
{[0.12]}\end{array}$ & $\begin{array}{l}0.22^{\star *} \\
{[0.08]}\end{array}$ \\
\hline Remittances & $\begin{array}{c}0.49 \\
{[0.40]}\end{array}$ & $\begin{array}{c}0.94 \\
{[0.54]}\end{array}$ & $\begin{array}{c}-0.08 \\
{[0.73]}\end{array}$ & $\begin{array}{l}-0.27 \\
{[0.46]}\end{array}$ & $\begin{array}{c}0.28 \\
{[0.36]}\end{array}$ & $\begin{array}{c}-0.08 \\
{[0.27]}\end{array}$ & $\ldots$ & $\begin{array}{l}\cdots \\
\cdots\end{array}$ & $\begin{array}{l}\cdots \\
\cdots\end{array}$ \\
\hline \multicolumn{10}{|c|}{ Hodrick-Prescott cyclical component model - estimated factor loadings } \\
\hline US cycle & $\begin{array}{l}-0.13 \\
{[0.58]}\end{array}$ & $\begin{array}{l}-0.10 \\
{[0.68]}\end{array}$ & $\begin{array}{l}-0.06 \\
{[0.58]}\end{array}$ & $\begin{array}{c}0.09 \\
{[0.48]}\end{array}$ & $\begin{array}{c}0.14 \\
{[0.34]}\end{array}$ & $\begin{array}{l}0.66^{*} \\
{[0.35]}\end{array}$ & $\begin{array}{c}0.29 * \star \star \\
{[0.06]}\end{array}$ & $\begin{array}{c}0.32^{\star \star \star} \\
{[0.05]}\end{array}$ & $\begin{array}{c}0.24^{\star \star \star} \\
{[0.06]}\end{array}$ \\
\hline Remittances & $\begin{array}{l}0.55^{\star \star} \\
{[0.22]}\end{array}$ & $\begin{array}{l}0.67^{\star \star} \\
{[0.30]}\end{array}$ & $\begin{array}{c}0.31 \\
{[0.49]}\end{array}$ & $\begin{array}{l}-0.33 \\
{[0.57]}\end{array}$ & $\begin{array}{c}0.32 \\
{[0.42]}\end{array}$ & $\begin{array}{l}-0.02 \\
{[0.33]}\end{array}$ & $\begin{array}{l}\cdots \\
\ldots\end{array}$ & $\begin{array}{l}\cdots \\
\cdots\end{array}$ & $\begin{array}{l}\cdots \\
\ldots\end{array}$ \\
\hline
\end{tabular}

Source: Authors' calculations.

$1 /$ The coefficients are the factor loadings (or sensitivity) of each variable in the observable vector to the unobservable factors which represent the U.S. cycle and a common remittance effect. These results were based on estimations using the cyclical component of the Hodrick-Prescott filter. Significance at 1,5 , and 10 percent levels indicated by ***, ${ }^{* \star}$, and * respectively. Coefficient standard errors are in brackets.

As a plausibility check on the results, we plotted the two estimated state variables - the U.S. cycle and the common remittance factor-to assess whether they make intuitive sense (see Figure A7). The U.S. cycle factor seems reasonable, tracing out the cyclical downturns of the early 1990s and the 2001-02 period. The remittance factor exhibits far less persistence and is characterized by a number of sharp spikes; as Figure A8-which imposes the Latin EMBI+ sovereign debt spread-suggests, this is likely related to the occurrence of economic or financial crisis in certain countries in the region. This is consistent with the "insurance" motive suggested in other work (e.g. Yang and Choi, 2007).

\section{Conclusion}

Using a range of methods, we find no compelling evidence of linkages between the U.S. business cycle and remittance flows to Latin America over the sample period 19902007. This may not be so surprising, since there are hypotheses that can go some way toward explaining this result.

It is possible that migrant workers "smooth" their remittance flows in much the same way they might smooth consumption. This would mean that remittances would be less volatile than income; for example, migrants may send a fixed U.S. dollar amount each month or quarter, irrespective of income fluctuations, within reason. There is survey evidence from the UK to support this hypothesis, with immigrants showing a propensity to remit a fixed amount at regular periods (Boon, 2006). In turn, this would require access to financial services, to save in good times and to borrow in tough times, which is more likely for established 
migrants. This hypothesis is grounded in microeconomics and, given the aggregate nature of this study, it cannot be pushed too far in support of our results. A more rigorous test would be provided by an analysis that used per capita data.

An alternative explanation is that the supply of immigrant labor is relatively inflexible. Possibly lacking savings or other means of employment insurance, and having a strong incentive to remit to families that may live in relative poverty, could imply that immigrants have a lower "reservation" wage than the average worker. The consequence would be that immigrants would attach more weight to being employed than to the wage received, and thus are less likely to be unemployed (ceritus paribus) than their native-born counterparts. There is some evidence in the literature that immigrants do indeed have lower unemployment rates, controlling for other relevant factors (e.g. Miller and Meo, 2003; and Chiswick and Hurst, 2000). Other research has indicated that the duration of unemployment spells for immigrants is significantly lower than that for native-born workers (Hansen, 2000).

There might also be significant measurement error, as highlighted above. One particularly relevant issue is that the decline in the costs of sending remittances through formal mechanisms has declined, encouraging more migrants to use these services. If true, then it is likely that some portion of the sharp rise in the level of remittances captured in official statistics is due to the diversion of existing remittances flows and that this effect is damping the apparent effect of economic fluctuations in the host country.

It is too early to conclude that remittances will remain completely immune to the host country business cycle. Certainly, at an individual level it is difficult to argue against a link between income and the capacity to remit. Also, our sample size is short for many countries and significant uncertainties remain about data reliability. Indeed, while the recent decline in remittances to Mexico - the most celebrated recent example - may be attributed to increased border security, greater immigrant insecurity leading to increased saving (IDB, 2007), or even the slowing down in remittance diversion following sharp declines in transfer costs, it may also signal the beginning of such a linkage. That said, all of the evidence we have before us today suggests that remittance flows to Latin America remain relatively insensitive to fluctuations in the U.S. economic cycle, underlining their role as a stable source of external financing, in good times and bad. ${ }^{6}$

\footnotetext{
${ }^{6}$ A summary of this survey is available at: http://www.iadb.org/news/articledetail.cfm?artid=3985\&language=english
} 


\section{References}

Attzs, Marlene and Wendell Samuel, 2007. "Natural Disasters and Remittances in Central America and the Caribbean,” Mimeo.

Aydas, Osman Tuncay, Kivilcim Metin-Ozcan \& Bilin Neyapti, 2005. "Determinants of Workers' Remittances: The Case of Turkey,” Emerging Markets Finance and Trade, Vol. 41(3), pp. 53-69.

Boon, Martin, 2006, BME Remittance Survey, ICM Research, London.

Cheung, Y. and K. S. Lai, 1993. "Finite-sample sizes of Johansen's likelihood ratio tests for cointegration,” Oxford Bulletin of Economics and Statistics, No. 55, pp. 313-28.

Chiswick, Barry, R., and Michael E. Hurst, 2000, “The Employment, Unemployment and Unemployment Compensation Benefits of Immigrants,” in Bassi, Lauri J. and Woodbury, Stephen A., (eds), Long-Term Unemployment and Reemployment Policies, Research in Employment Policy, Vol. 2, JAI Press, Stamford, CN, pp. 87115.

Croux, Christophe, Eric Renault, and Bas Werker, 2004, “Dynamic Factor Models,” Journal of Econometrics, Volume 119, Issue 2, pp. 223-230.

El-Sakka, M. I. T. and Robert McNabb. “The Macroeconomic Determinants of Emigrant Remittances,” World Development, Vol. 27(8), pp. 1493-1502.

Freund, Caroline L. and Nikola Spatafora, 2005. "Remittances: Transaction Costs, Determinants, and Informal Flows,” World Bank Policy Research Working Paper, No. 3704.

Funkhouser, Edward, 1995. "Remittances from International Migration: A Comparison of El Salvador and Nicaragua,” Review of Economics and Statistics, Vol. 77, No. 1, pp. 137-146.

Giuliano, Paola and Marta Ruiz-Arranz, 2006, "Remittances, Financial Development, and Growth,” IZA Working Paper No. 2160.

Gupta, Poonam, 2005, “Macroeconomic Determinants of Remittances: Evidence from India,” IMF Working Paper, WP/05/224. 
Gutiérrez, Tuirán, Rodolfo, Jorge Santibáñez Romellón, Rodolfo Corona Vázquez, 2006. “El monto de las remesas familiares en México: ¿mito o realidad?” Papeles de Población, No. 050, pp. 147-169.

Hansen, Jörgen, 2000. “The Duration of Immigrants' Unemployment Spells: Evidence from Sweden,” IZA Discussion Papers, 155, Institute for the Study of Labor (IZA).

Lianos, Theodore P. (1997), "Factors Determining Migrant Remittances: The Case of Greece,” International Migration Review, Vol. 31, No. 1. (Spring, 1997), pp. $72-87$.

Lowell, B. Lindsay and Rodolfo O. De La Garza, 2000, "The Developmental Role of Remittances in U.S. Latino Communities and in Latin American Countries," InterAmerican Dialogue and the Thomas Rivera Policy Institute.

Lueth, Erik, and Maria Ruiz-Arranz, 2006, “A Gravity Model of Workers’ Remittances,” IMF Working Paper, WP/06/290.

Miller, Paul W. and Leanne M. Neo, 2003, "Labour Market Flexibility and Immigrant Adjustment,” Economic Record 79 (246), 336-356.

Orozco, Manuel, 2004. "The Remittance Marketplace: Prices, Policy and Financial Institutions,” Pew Hispanic Center Report, Washington, D.C.

Orozco, Manuel, 2006, "International Flows of Remittances: Cost, competition and financial access in Latin America and the Caribbean - toward an industry scorecard," InterAmerican Dialogue, Washington, DC May 12, 2006.

Rapoport, Hillel and Frédéric Docquier, 2005, “The Economics of Migrants’ Remittances,” IZA Discussion Papers 1531, Institute for the Study of Labor (IZA).

Rhyne, Elisabeth, 2007, "The Role of Remittances in Leveraging Sustainable Development in Latin American and the Caribbean," Testimony before the Subcommittee on Domestic and International Monetary Policy, Trade, and Technology, U.S. House of Representatives.

Stark, O., 1995, Altruism and Beyond, Oxford and Cambridge: Basil Blackwell.

Stock, James, and Mark Watson, 1988. “Testing for Common Trends,” Journal of the American Statistical Association, No. 83, pp. 1097-1107.

United Nations, 2005. Balance of Payments Technical Expert Group (BOPTEG) Outcome Paper \#9B, Statistics Division, Department of Economic and Social Affairs, New York. 
Vargas-Silva, Carlos and Peng Huang, 2006. "Macroeconomic determinants of workers' remittances: Host versus home country's economic conditions,” Journal of International Trade \& Economic Development, Vol. 15(1), pp. 81-99.

Yang, Dean and HwaJung Choi, 2007, “Are Remittances Insurance? Evidence from Rainfall Shocks in the Philippines,” The World Bank Economic Review (forthcoming). 


\section{Appendix}

\section{Table A1. Levels VAR Lag Length Tests and Information Criteria 1/}

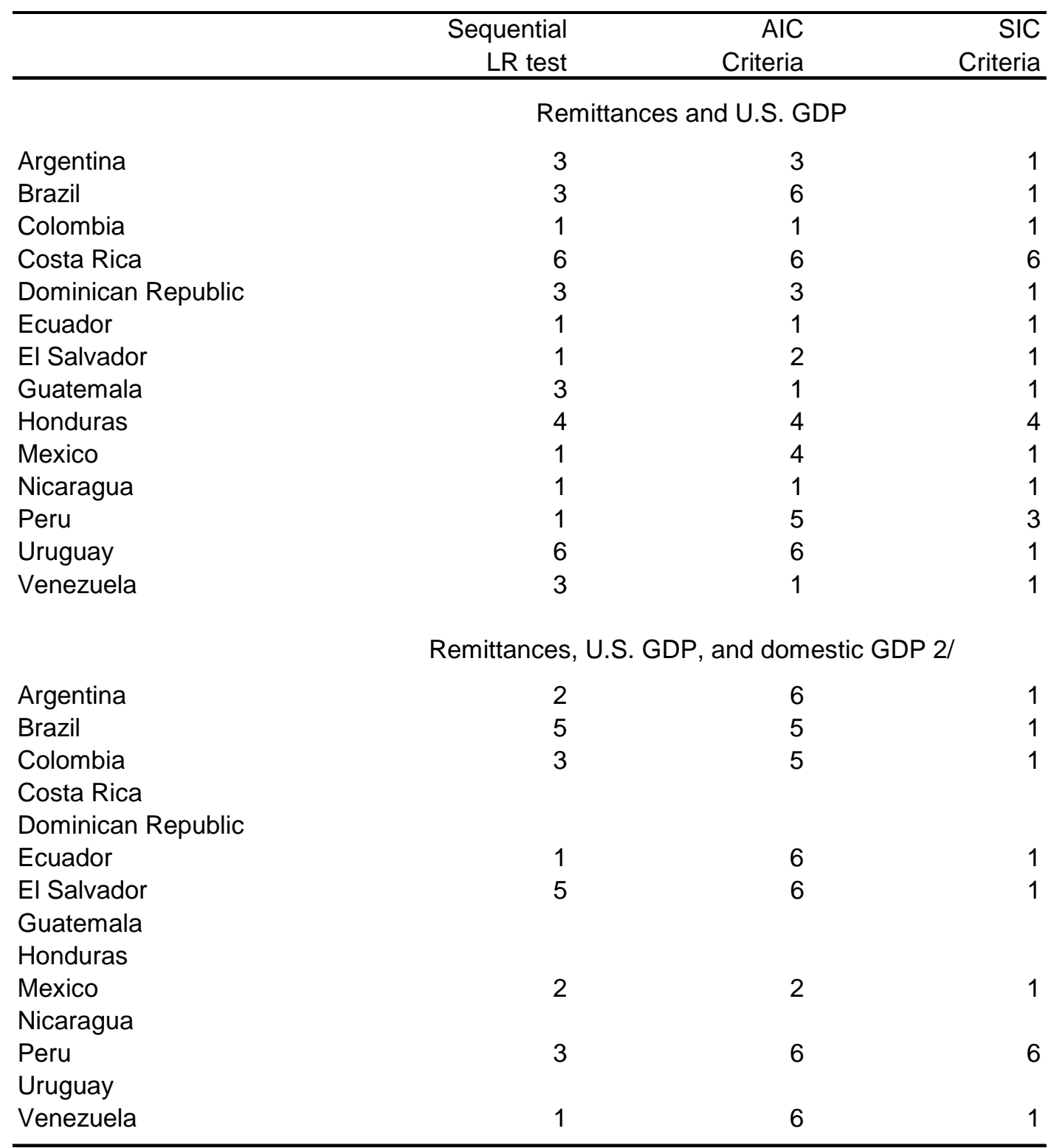

Source: Authors' calculations.

1/ Figures indicate the lag length selected by each test and criteria.

2/ Results are reported only for countries that provide GDP on a quarterly basis and have a sufficient number of observations for estimation. 
Table A2. Cointegration Tests: Probability Values from the Engle-Granger Procedure 1/

\begin{tabular}{lrrrrrr}
\hline & $\begin{array}{r}\text { Housing } \\
\text { starts }\end{array}$ & GDP & $\begin{array}{r}\text { Construction } \\
\text { employment }\end{array}$ & $\begin{array}{r}\text { Services } \\
\text { employment }\end{array}$ & $\begin{array}{r}\text { ISM } \\
\text { Index }\end{array}$ & $\begin{array}{r}\text { Retail } \\
\text { sales }\end{array}$ \\
\hline Argentina & $\mathbf{0 . 0 2 6}$ & $\mathbf{0 . 0 1 8}$ & $\mathbf{0 . 0 1 2}$ & $\mathbf{0 . 0 0 0}$ & $\mathbf{0 . 0 0 1}$ & $\mathbf{0 . 0 2 1}$ \\
Brazil & 0.090 & 0.082 & 0.130 & 0.139 & 0.093 & 0.066 \\
Colombia & 0.135 & $\mathbf{0 . 0 3 5}$ & 0.096 & 0.055 & 0.282 & $\mathbf{0 . 0 2 3}$ \\
Costa Rica & 0.506 & $\mathbf{0 . 0 0 8}$ & $\mathbf{0 . 0 0 7}$ & $\mathbf{0 . 0 0 9}$ & 0.188 & $\mathbf{0 . 0 0 6}$ \\
Dominican Republic & 0.173 & $\mathbf{0 . 0 0 0}$ & 0.058 & $\mathbf{0 . 0 2 4}$ & $\mathbf{0 . 0 1 6}$ & $\mathbf{0 . 0 0 0}$ \\
Ecuador & 0.629 & $\mathbf{0 . 0 0 6}$ & $\mathbf{0 . 0 1 0}$ & $\mathbf{0 . 0 0 1}$ & 0.245 & $\mathbf{0 . 0 1 6}$ \\
El Salvador & 0.726 & $\mathbf{0 . 0 0 0}$ & 0.053 & $\mathbf{0 . 0 3 5}$ & 0.325 & 0.102 \\
Guatemala & 0.645 & 0.126 & 0.221 & 0.211 & 0.351 & 0.394 \\
Honduras & 0.114 & $\mathbf{0 . 0 0 4}$ & $\mathbf{0 . 0 0 1}$ & 0.269 & 0.175 & 0.102 \\
Mexico & 0.774 & 0.094 & 0.229 & 0.195 & 0.289 & 0.343 \\
Nicaragua & 0.349 & 0.096 & $\mathbf{0 . 0 0 4}$ & $\mathbf{0 . 0 0 3}$ & $\mathbf{0 . 0 1 4}$ & 0.101 \\
Peru & 0.859 & $\mathbf{0 . 0 0 0}$ & $\mathbf{0 . 0 3 0}$ & 0.078 & 0.674 & $\mathbf{0 . 0 1 8}$ \\
Uruguay & 0.105 & $\mathbf{0 . 0 3 0}$ & 0.090 & $\mathbf{0 . 0 0 0}$ & $\mathbf{0 . 0 0 7}$ & $\mathbf{0 . 0 0 5}$ \\
Venezuela & $\mathbf{0 . 0 2 6}$ & 0.067 & 0.088 & 0.121 & $\mathbf{0 . 0 0 6}$ & 0.064 \\
\hline
\end{tabular}

Source: Authors' calculations.

$1 /$ Null hypothesis is that the level of remittances and the economic indicator are not cointegrated. The lag length used in the test was selected by the Schwarz Information Criterion. Figures in bold indicate where the null hypothesis may be rejected at the 5 percent level of significance.

Table A3. Cointegration Tests for Remittances and U.S. GDP 1/

\begin{tabular}{|c|c|c|c|c|c|c|c|c|}
\hline & \multirow[b]{3}{*}{$\begin{array}{r}\text { Sample } \\
\text { size }\end{array}$} & \multirow[b]{3}{*}{$\begin{array}{r}\text { Lag length } \\
\text { test } 2 / \\
\end{array}$} & \multirow[b]{3}{*}{$\begin{array}{r}\text { Engle Granger } \\
\mathrm{p} \text {-value }\end{array}$} & \multicolumn{4}{|c|}{ Johansen tests } & \multirow[b]{3}{*}{$\begin{array}{r}\text { Reject } \\
\text { null 3/ } \\
\end{array}$} \\
\hline & & & & \multicolumn{2}{|c|}{$\operatorname{Lag} 2$} & \multicolumn{2}{|c|}{$\operatorname{Lag} 4$} & \\
\hline & & & & $\begin{array}{r}\text { Trace } \\
\text { p-value }\end{array}$ & $\begin{array}{r}\text { Maxeigen } \\
\text { p-value } \\
\end{array}$ & $\begin{array}{r}\text { Trace } \\
\text { p-value }\end{array}$ & $\begin{array}{r}\text { Maxeigen } \\
\text { p-value }\end{array}$ & \\
\hline Argentina & 52 & 3 & 0.02 & 0.40 & 0.34 & 0.36 & 0.28 & No \\
\hline Brazil & 49 & 3 & 0.08 & 0.08 & 0.06 & 0.00 & 0.00 & Yes \\
\hline Colombia & 44 & 1 & 0.04 & 0.69 & 0.79 & 0.23 & 0.26 & No \\
\hline Costa Rica & 19 & 6 & 0.01 & 0.12 & 0.08 & 0.13 & 0.11 & No \\
\hline Dominican Republiı & 36 & 3 & 0.00 & 0.05 & 0.04 & 0.68 & 0.60 & No \\
\hline Ecuador & 32 & 1 & 0.01 & 0.35 & 0.30 & 0.66 & 0.57 & No \\
\hline El Salvador & 37 & 1 & 0.00 & 0.01 & 0.00 & 0.01 & 0.01 & Yes \\
\hline Guatemala & 53 & 3 & 0.13 & 0.81 & 0.78 & 0.43 & 0.35 & No \\
\hline Honduras & 17 & 4 & 0.00 & 0.00 & 0.01 & 0.00 & 0.05 & No \\
\hline Mexico & 49 & 1 & 0.09 & 0.29 & 0.33 & 0.27 & 0.21 & No \\
\hline Nicaragua & 28 & 1 & 0.10 & 0.02 & 0.01 & 0.02 & 0.03 & Yes \\
\hline Peru & 68 & 1 & 0.00 & 0.01 & 0.02 & 0.01 & 0.02 & Yes \\
\hline Uruguay & 28 & 6 & 0.03 & 0.33 & 0.26 & 0.01 & 0.01 & Yes \\
\hline Venezuela & 40 & 3 & 0.07 & 0.11 & 0.08 & 0.13 & 0.09 & No \\
\hline
\end{tabular}

Source: Authors' calculations.

$1 /$ Null hypothesis is that the level of remittances and the economic indicator are not cointegrated. The lag length used in the Engle-Granger test was selected by the Schwarz Information Criterion.

Figures in bold indicate where the null hypothesis may be rejected at the 5 percent level of significance.

2/ Based on sequential small-sample modified log-likelihood ratio tests.

$3 /$ If the sample size is greater than 20, the null of no cointgeration is rejected if at least 2 out of 3 of the cointegration tests can be rejected at the 5 percent level of significance. The lag lengths for the Johansen tests are based on the LR lag length exclusion test. 
Table A4. Johansen Cointegration Tests for Remittances and U.S. GDP 1/

\begin{tabular}{|c|c|c|c|c|c|c|}
\hline & \multicolumn{2}{|c|}{ Lag length 4} & \multicolumn{2}{|c|}{ Lag length 6} & \multicolumn{2}{|c|}{ Lag length 8} \\
\hline & Trace & Maxeigen & Trace & Maxeigen & Trace & Maxeigen \\
\hline Argentina & 0.36 & 0.28 & 0.10 & 0.07 & 0.07 & 0.05 \\
\hline Brazil & 0.00 & 0.00 & 0.08 & 0.06 & 0.00 & 0.00 \\
\hline Colombia & 0.23 & 0.26 & 0.43 & 0.40 & 0.03 & 0.05 \\
\hline Costa Rica & 0.13 & 0.11 & & & & \\
\hline Dominican Republic & 0.68 & 0.60 & 0.24 & 0.19 & 0.00 & 0.00 \\
\hline Ecuador & 0.66 & 0.57 & 0.07 & 0.07 & 0.00 & 0.00 \\
\hline El Salvador & 0.01 & 0.01 & 0.64 & 0.59 & 0.00 & 0.00 \\
\hline Guatemala & 0.43 & 0.35 & 0.02 & 0.02 & 0.01 & 0.01 \\
\hline Honduras & & & & & & \\
\hline Mexico & 0.27 & 0.21 & 0.31 & 0.37 & 0.36 & 0.28 \\
\hline Nicaragua & 0.02 & 0.03 & 0.00 & 0.00 & & \\
\hline Peru & 0.01 & 0.02 & 0.00 & 0.00 & & \\
\hline Uruguay & 0.01 & 0.01 & 0.09 & 0.06 & & \\
\hline Venezuela & 0.13 & 0.09 & 0.14 & 0.12 & 0.00 & 0.00 \\
\hline
\end{tabular}

Source: Authors' calculations.

$1 /$ Null hypothesis is that the level of remittances and the level of U.S. GDP are not cointegrated. The lag length used in the test was selected by the sequential small sample adjusted log-likelihood ratio test.

Figures in bold indicate where the null hypothesis may be rejected at the 5 percent level of significance.

Table A5. Johansen Cointegration Tests for Remittances, U.S. GDP, and Domestic GDP 1/

\begin{tabular}{|c|c|c|c|c|c|c|c|c|}
\hline & \multirow{2}{*}{$\begin{array}{r}\text { Lag length } \\
\text { test }\end{array}$} & \multicolumn{2}{|c|}{ Lag length 2} & \multicolumn{2}{|c|}{ Lag length 4} & \multicolumn{2}{|c|}{ Lag length 6} & \multirow{2}{*}{$\begin{array}{l}\text { Reject } \\
\text { null 2/ }\end{array}$} \\
\hline & & Trace & Maxeigen & Trace & Maxeigen & Trace & Maxeigen & \\
\hline Argentina & 2 & 0.21 & 0.16 & 0.02 & 0.01 & 0.02 & 0.01 & No \\
\hline Brazil & 5 & 0.12 & 0.24 & 0.00 & 0.00 & 0.01 & 0.01 & Yes \\
\hline Colombia & 3 & 0.34 & 0.70 & 0.02 & 0.03 & 0.01 & 0.08 & No \\
\hline \multicolumn{9}{|l|}{ Costa Rica } \\
\hline \multicolumn{9}{|c|}{ Dominican Republic } \\
\hline Ecuador & 1 & 0.00 & 0.00 & 0.00 & 0.00 & 0.00 & 0.00 & No \\
\hline El Salvador & 6 & 0.01 & 0.07 & 0.01 & 0.01 & 0.00 & 0.00 & Yes \\
\hline \multicolumn{9}{|l|}{ Guatemala } \\
\hline \multicolumn{9}{|l|}{ Honduras } \\
\hline Mexico & 2 & 0.13 & 0.07 & 0.06 & 0.12 & 0.03 & 0.10 & No \\
\hline \multicolumn{9}{|l|}{ Nicaragua } \\
\hline Peru & 6 & 0.03 & 0.06 & 0.00 & 0.00 & & & Yes \\
\hline Uruguay & 1 & 0.07 & 0.23 & 0.00 & 0.00 & & & No \\
\hline Venezuela & 1 & 0.05 & 0.17 & 0.00 & 0.00 & 0.00 & 0.00 & No \\
\hline
\end{tabular}

Source: Authors' calculations.

$1 /$ Null hypothesis is that the level of remittances and the level of U.S. GDP are not cointegrated. The lag length used in the test was selected by the sequential small sample adjusted log-likelihood ratio test.

Figures in bold indicate where the null hypothesis may be rejected at the 5 percent level of significance.

$2 /$ If the sample size is greater than 20 , the null of no cointgeration is rejected if at least 1 of the cointegration tests can be rejected at the 5 percent level of significance. 


\section{Table A6. Distributed Lag Estimations -- Results Summary 1/}

Polynomial Distributed Lag Specification without origin country control Sum of coefficients R F-statistic on U.S. variable squared ( $p$-value)
Polynomial Distributed Lag Specification with origin country control

\begin{tabular}{cccc}
\hline \multicolumn{2}{c}{ Sum of coefficients } & $\mathrm{R}$ & F-statistic \\
\cline { 1 - 2 } on U.S. variable & on origin GDP & squared & $(p$-value $)$ \\
\hline
\end{tabular}

U.S. Housing Starts

\begin{tabular}{|c|c|c|c|c|c|c|c|}
\hline Argentina & -1.0 & 0.13 & 0.09 & -0.9 & -0.2 & 0.14 & 0.37 \\
\hline Brazil & 2.4 & 0.09 & 0.24 & -0.5 & 2.9 & 0.15 & 0.34 \\
\hline Colombia & 0.7 & 0.32 & 0.01 & -1.2 & $-3.9 * *$ & 0.51 & 0.00 \\
\hline Costa Rica & 0.3 & 0.22 & 0.28 & -0.1 & -0.3 & 0.33 & 0.47 \\
\hline Ecuador & 0.6 & 0.34 & 0.03 & 0.9 & 2.1 & 0.50 & 0.03 \\
\hline El Salvador & 0.4 & 0.04 & 0.69 & 0.2 & 0.1 & 0.18 & 0.66 \\
\hline Mexico & 0.2 & 0.11 & 0.16 & 0.2 & -0.5 & 0.13 & 0.40 \\
\hline Peru & 0.9 & 0.26 & 0.20 & 0.4 & 2.5 & 0.31 & 0.31 \\
\hline Uruguay & 0.1 & 0.03 & 0.86 & 2.6 & -2.3 & 0.09 & 0.93 \\
\hline \multirow[t]{2}{*}{ Venezuela } & -1.1 & 0.22 & 0.03 & 0.0 & -0.4 & 0.20 & 0.27 \\
\hline & \multicolumn{7}{|c|}{ U.S. Gross Domestic Product } \\
\hline Argentina & -3.1 & 0.15 & 0.12 & 4.8 & -1.2 & 0.14 & 0.36 \\
\hline Brazil & -5.3 & 0.05 & 0.54 & -11.8 & 4.1 & 0.18 & 0.21 \\
\hline Colombia & -2.8 & 0.15 & 0.10 & -3.1 & -2.9 & 0.36 & 0.01 \\
\hline Costa Rica & -7.6 & 0.17 & 0.42 & -8.8 & -0.9 & 0.19 & 0.81 \\
\hline Ecuador & 5.1 & 0.14 & 0.24 & 6.7 & 1.2 & 0.36 & 0.21 \\
\hline El Salvador & 2.3 & 0.17 & 0.11 & 2.6 & -1.4 & 0.26 & 0.34 \\
\hline Mexico & -1.8 & 0.27 & 0.00 & -2.1 & 0.0 & 0.32 & 0.01 \\
\hline Peru & 6.6 ** & 0.29 & 0.07 & 7.6 & 0.1 & 0.29 & 0.38 \\
\hline Uruguay & -21.7 & 0.12 & 0.45 & -39.2 & 2.2 & 0.10 & 0.91 \\
\hline \multirow[t]{2}{*}{ Venezuela } & 19.6 ** & 0.27 & 0.01 & 21.1 ** & -2.6 & 0.42 & 0.02 \\
\hline & \multicolumn{7}{|c|}{ U.S. Construction Employment } \\
\hline Argentina & -3.1 & 0.07 & 0.31 & -0.7 & -0.1 & 0.12 & 0.46 \\
\hline Brazil & -6.5 & 0.11 & 0.15 & -4.8 & 0.3 & 0.18 & 0.20 \\
\hline Colombia & -0.2 & 0.03 & 0.73 & -0.4 & -2.4 & 0.36 & 0.04 \\
\hline Costa Rica & 0.7 & 0.04 & 0.89 & 2.1 & -3.4 & 0.11 & 0.95 \\
\hline Ecuador & 0.8 & 0.08 & 0.53 & 0.7 & 0.4 & 0.21 & 0.42 \\
\hline El Salvador & 0.6 & 0.09 & 0.40 & 0.3 & -0.4 & 0.31 & 0.38 \\
\hline Mexico & -1.2 & 0.09 & 0.23 & -1.5 & 0.0 & 0.14 & 0.37 \\
\hline Peru & 1.9 & 0.28 & 0.08 & -1.8 & 5.3 * & 0.43 & 0.27 \\
\hline Uruguay & -5.5 & 0.42 & 0.05 & -15.8 & 4.0 & 0.53 & 0.21 \\
\hline Venezuela & 9.0 ** & 0.14 & 0.15 & 9.7 & -1.2 * & 0.24 & 0.22 \\
\hline
\end{tabular}

Source: Authors' estimates.

$1 /{ }^{* *}\left(^{\star}\right)$ implies significance at the 5 (10) percent level. 
Table A6 (continued). Distributed Lag Estimations -- Results Summary 1/

Polynomial Distributed Lag Specification without origin country control

Sum of coefficients $\mathrm{R} \quad$ F-statistic on U.S. variable squared ( $p$-value)
Polynomial Distributed Lag Specification with origin country control

\begin{tabular}{cccc}
\hline \multicolumn{2}{c}{ Sum of coefficients } & $\mathrm{R}$ & F-statistic \\
\cline { 1 - 2 } on U.S. variable & on origin GDP & squared & $(p$-value) \\
\hline
\end{tabular}

U.S. Services Employment

\begin{tabular}{|c|c|c|c|c|c|c|c|}
\hline Argentina & -3.5 & 0.15 & 0.12 & -4.8 & -1.1 & 0.34 & 0.06 \\
\hline Brazil & -12.2 * & 0.11 & 0.14 & -11.1 & 2.9 & 0.20 & 0.14 \\
\hline Colombia & -1.1 & 0.06 & 0.46 & -3.3 & -3.0 & 0.23 & 0.13 \\
\hline Costa Rica & -9.1 & 0.09 & 0.69 & -4.4 & -6.9 & 0.20 & 0.79 \\
\hline Ecuador & 4.0 & 0.12 & 0.31 & 4.2 & 0.4 & 0.28 & 0.20 \\
\hline El Salvador & 2.1 & 0.30 & 0.05 & 0.7 & 0.9 & 0.14 & 0.60 \\
\hline Mexico & -3.4 & 0.07 & 0.35 & -2.9 & -0.5 & 0.09 & 0.68 \\
\hline Peru & 1.9 & 0.43 & 0.01 & -0.2 & 1.0 & 0.49 & 0.15 \\
\hline Uruguay & -17.6 & 0.26 & 0.18 & -26.1 & 1.8 & 0.45 & 0.39 \\
\hline Venezuela & 17.4 ** & 0.29 & 0.02 & 15.7 * & -0.9 & 0.35 & 0.11 \\
\hline & \multicolumn{7}{|c|}{ U.S. ISM Manufacturing Index } \\
\hline Argentina & 0.5 & 0.20 & 0.02 & 0.5 & -0.5 & 0.21 & 0.10 \\
\hline Brazil & 0.4 & 0.13 & 0.11 & 1.0 & 4.3 & 0.22 & 0.22 \\
\hline Colombia & -0.8 & 0.09 & 0.32 & -0.6 & -2.9 & 0.25 & 0.09 \\
\hline Costa Rica & 0.2 & 0.15 & 0.47 & -1.3 & -4.7 & 0.22 & 0.76 \\
\hline Ecuador & 1.0 * & 0.19 & 0.12 & -0.2 & 0.1 & 0.44 & 0.02 \\
\hline El Salvador & 0.2 & 0.29 & 0.03 & 0.2 & -0.2 & 0.29 & 0.26 \\
\hline Mexico & 0.0 & 0.05 & 0.47 & -0.3 & -0.7 & 0.08 & 0.73 \\
\hline Peru & 0.3 & 0.54 & 0.01 & 0.2 & 0.4 & 0.68 & 0.05 \\
\hline Uruguay & 1.8 & 0.14 & 0.36 & 3.0 & -0.6 & 0.20 & 0.62 \\
\hline Venezuela & -1.5 ** & 0.13 & 0.16 & $-1.8 * \star$ & 0.1 & 0.21 & 0.27 \\
\hline
\end{tabular}

Source: Authors' estimates.

$1 /{ }^{* *}\left({ }^{*}\right)$ implies significance at the $5(10)$ percent level. 
Table A7. Wald Tests on Factor Model Coefficients 1/

\begin{tabular}{|c|c|c|c|c|}
\hline & $\begin{array}{l}\text { Null } \\
\text { hypothesis }\end{array}$ & $\begin{array}{l}\text { Critical } \\
\text { value }\end{array}$ & $\begin{array}{c}\text { Degrees } \\
\text { of freedom }\end{array}$ & $\begin{array}{c}\text { Probability } \\
\text { value }\end{array}$ \\
\hline \multicolumn{5}{|c|}{ First-differenced data } \\
\hline Test 1 & $\beta_{\mathrm{i} 2}=0$ for all $\mathrm{i}$ & 2.9 & 6 & 0.8187 \\
\hline Test 2 & $\beta_{\mathrm{i} 2}=\beta_{\mathrm{i} 4}=0$ for all $\mathrm{i}$ & 4.8 & 12 & 0.9642 \\
\hline Test 3 & $\beta_{i 2}=\beta_{i 3}=\beta_{i 4}=0$ for all $i$ & 33.2 & 18 & 0.0157 \\
\hline Test 4 & $\beta_{\mathrm{i} 3}=0$ for all $\mathrm{i}$ & 9.8 & 6 & 0.1338 \\
\hline \multicolumn{5}{|c|}{ Hodrick Prescott filtered data } \\
\hline Test 1 & $\beta_{\mathrm{i} 2}=0$ for all $\mathrm{i}$ & 5.4 & 6 & 0.4946 \\
\hline Test 2 & $\beta_{\mathrm{i} 2}=\beta_{\mathrm{i} 4}=0$ for all $\mathrm{i}$ & 14.4 & 12 & 0.2780 \\
\hline Test 3 & $\beta_{\mathrm{i} 2}=\beta_{\mathrm{i} 3}=\beta_{\mathrm{i} 4}=0$ for all $\mathrm{i}$ & 26.9 & 18 & 0.0811 \\
\hline Test 4 & $\beta_{\mathrm{i} 3}=0$ for all $\mathrm{i}$ & 8.7 & 6 & 0.1918 \\
\hline
\end{tabular}

Source: Authors' calculations.

1/ The null for the test are, repectively:

(i) coefficients of zero on the contemporaneous common cyclical factor;

(ii) coefficients of zero on the contemporaneous and lagged common cyclical factor;

(iii) coefficients of zero on all factors;

(iv) coefficients of zero on the common remittance factor. 
Figure A1. Impulse Responses of Remittances to U.S. GDP 1/
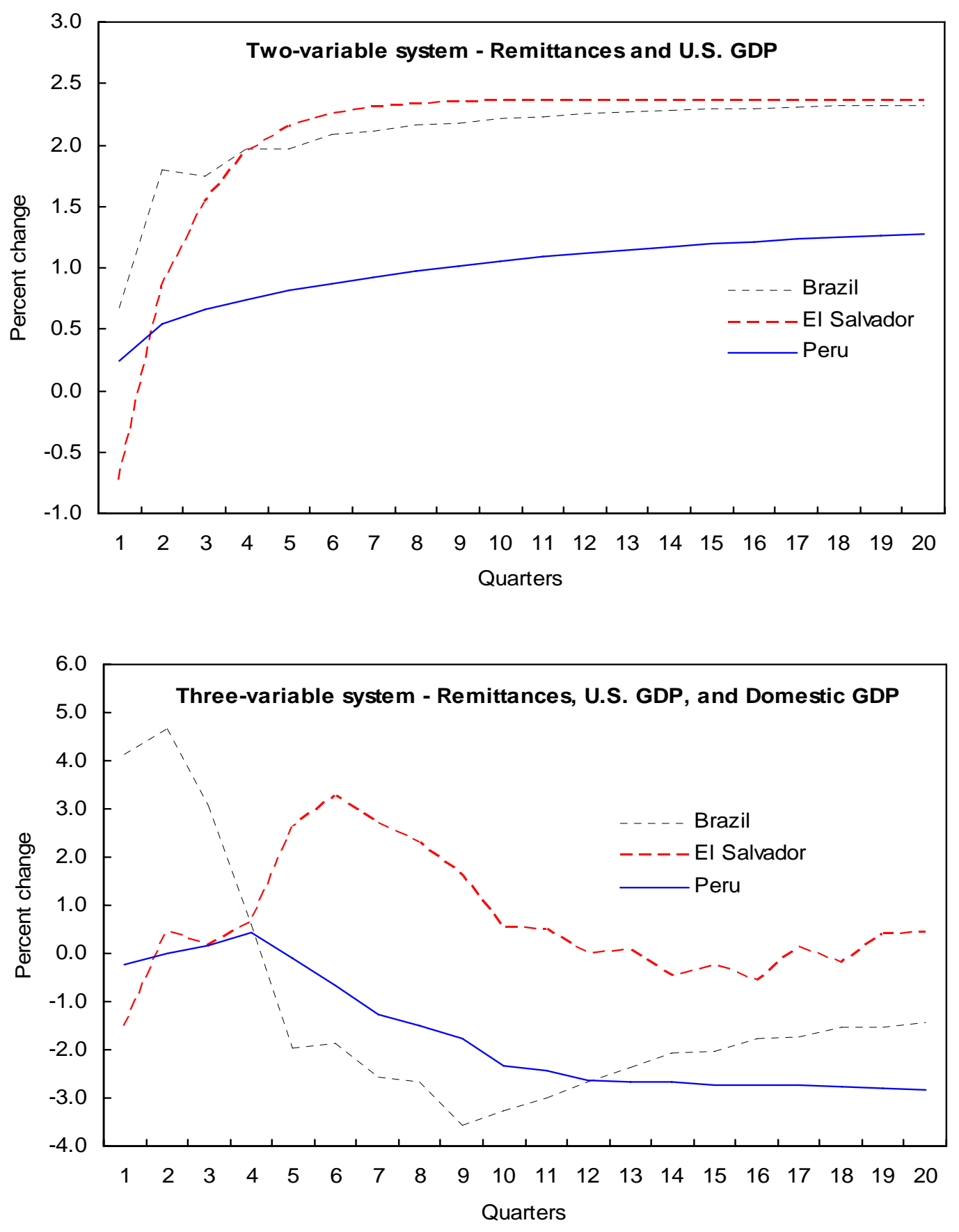

Source: Authors' calculations.

1/ Estimated impulse responses to a one standard deviation shock to U.S. GDP-which amounts to a 0.5 percent change quarter on quarter-from vector error correction (VECM) models with lag lengths chosen by the small sample adjusted LR test. 
Figure A2. Latin America: Correlation of Remittances to U.S. Economic Indicators by Indicator (first-differences) 1/ 2/
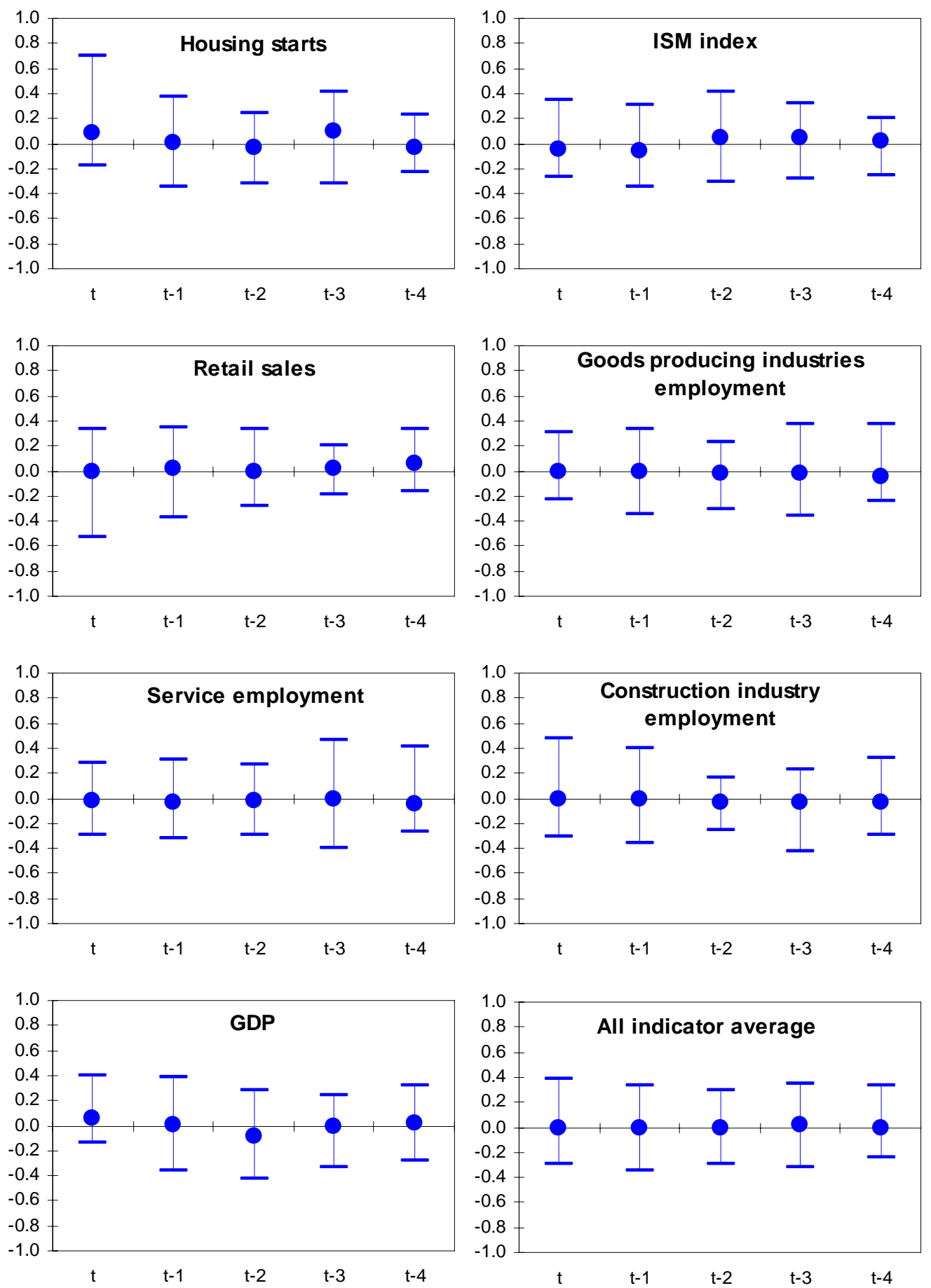

Source: National authorities; Haver analystics; and authors' calculations.

$1 /$ Charts show the lowest, highest, and mean correlation of each indicator to the sample of countries.

2/ Correlations use the first difference of the log for each series. The remittance series are seasonally-adjusted using the U.S. Census Bureau's X12 filter and deflated using U.S. CPI. 
Figure A3. Latin America: Correlation of Remittances to U.S. Financial and Housing Market Indicators by Indicator (first-differences) 1/ 2/
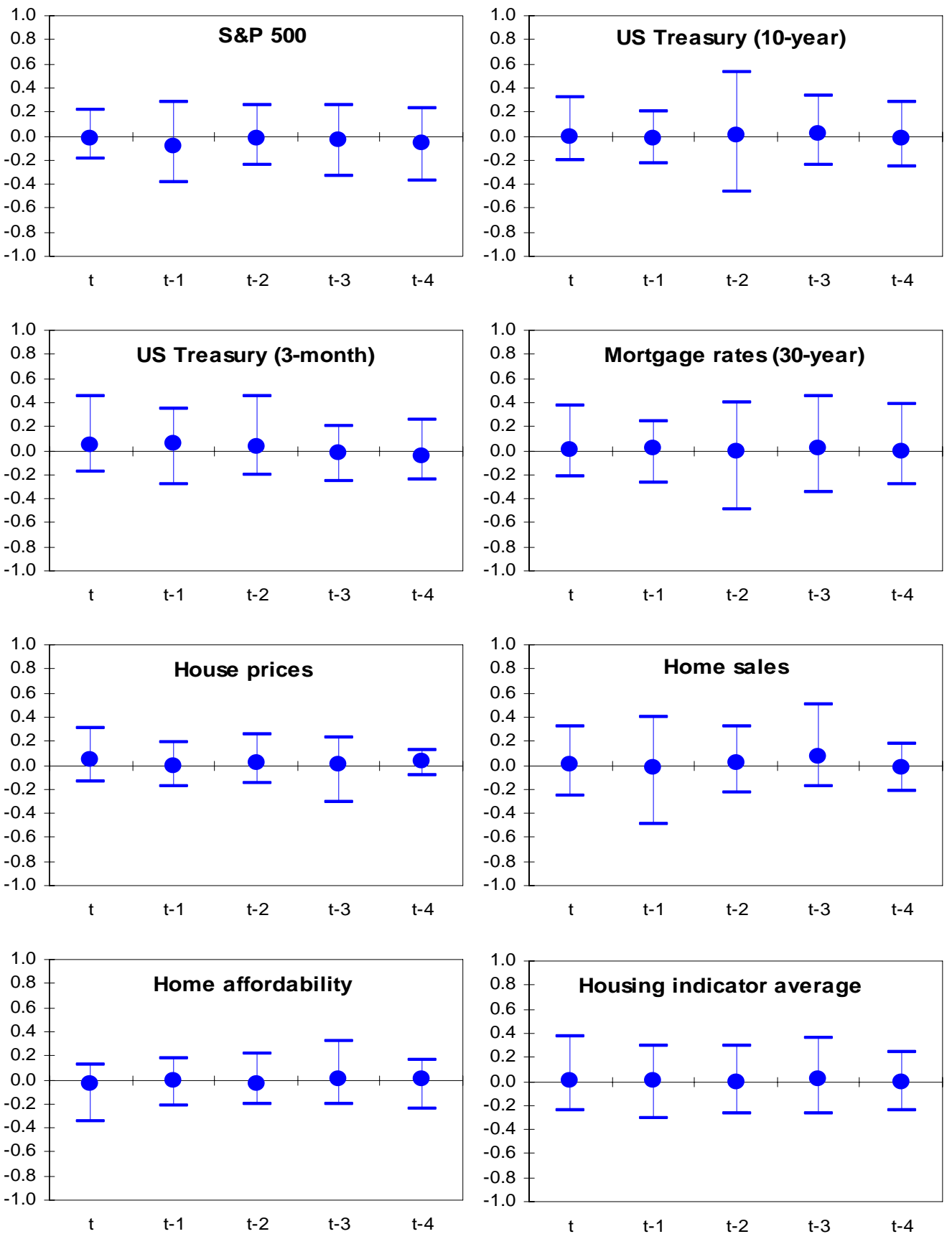

Source: National authorities; Haver analystics; and authors' calculations.

$1 /$ Charts show the lowest, highest, and mean correlation of each indicator to the sample of countries.

2/ Correlations use the first difference of the log for each series. The remittance series are seasonally-adjusted using the U.S. Census Bureau's X12 filter and deflated using U.S. CPI. 
Figure A4. Latin America: Correlation of Remittances to U.S. Economic Indicators by Country (first-differences) $1 / 2$ I
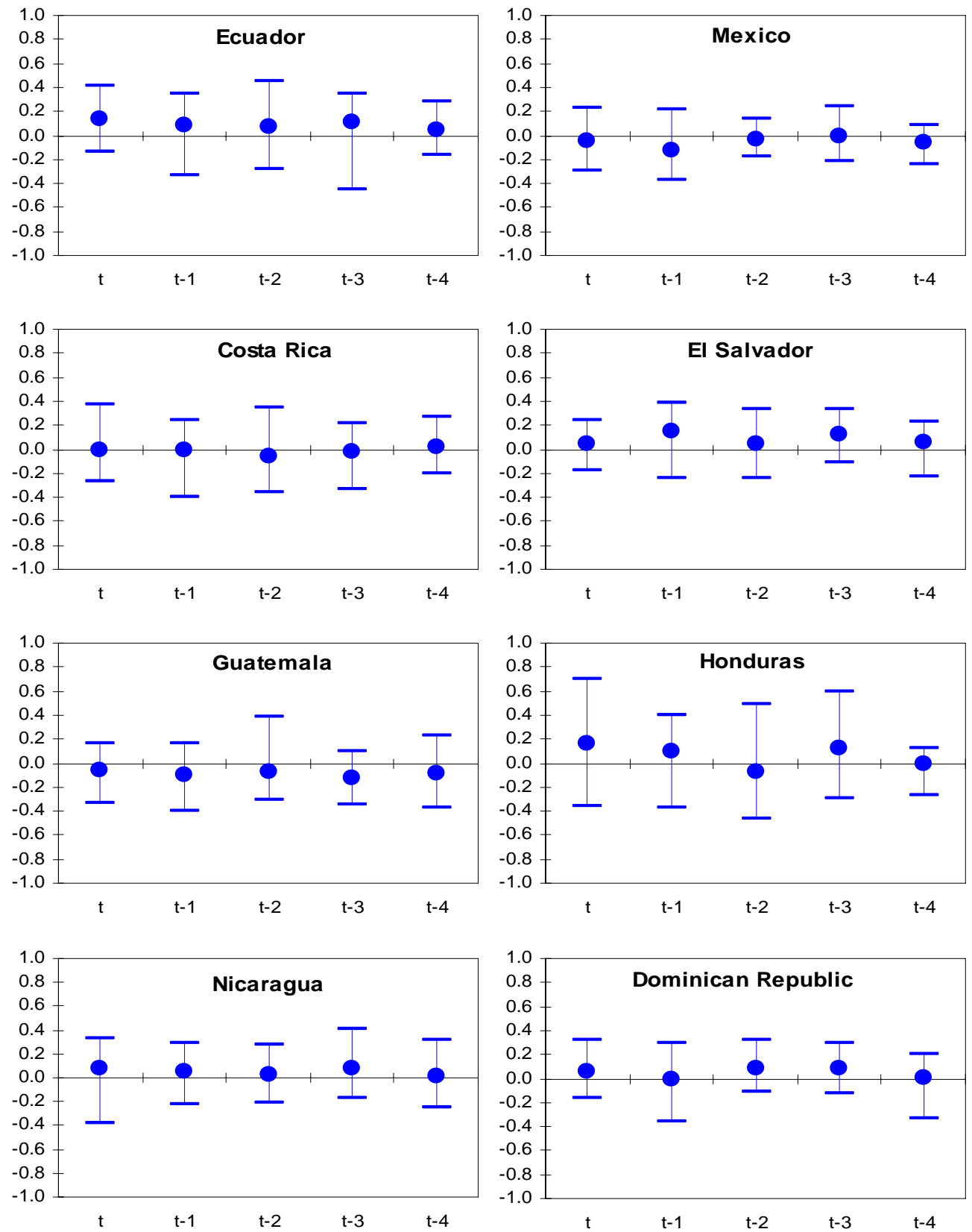

Source: National authorities; Haver analystics; and authors' calculations.

$1 /$ Charts show the lowest, highest, and mean correlation of each country to 8 cyclical U.S. economic indicators.

2/ Correlations use the first difference of the log for each series. The remittance series are seasonally-adjusted using the U.S. Census Bureau's X12 filter and deflated using U.S. CPI. 
Figure A5. Latin America: Correlation of Remittances to U.S. Housing Market Indicators by Country (first-differences) $1 / 2$ I
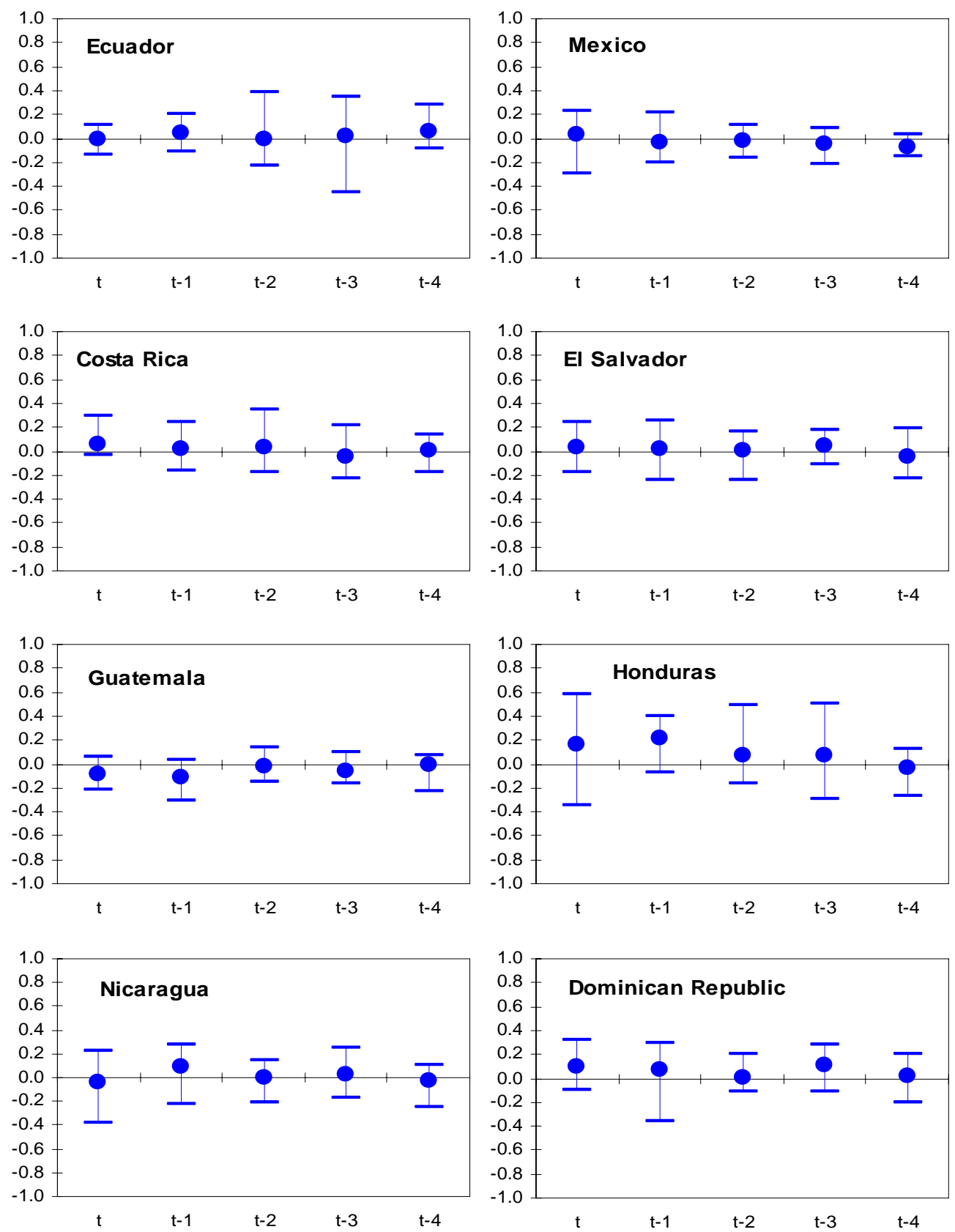

Source: National authorities; Haver analystics; and authors' calculations.

$1 /$ Charts show the lowest, highest, and mean correlation of each country to 8 cyclical U.S. economic indicators.

2/ Correlations use the first difference of the log for each series. The remittance series are seasonally-adjusted using the U.S. Census Bureau's X12 filter and deflated using U.S. CPI. 
Figure A6. Mexico Correlations with U.S. Economic Indicators Highest Correlations at Different Lags $1 /$
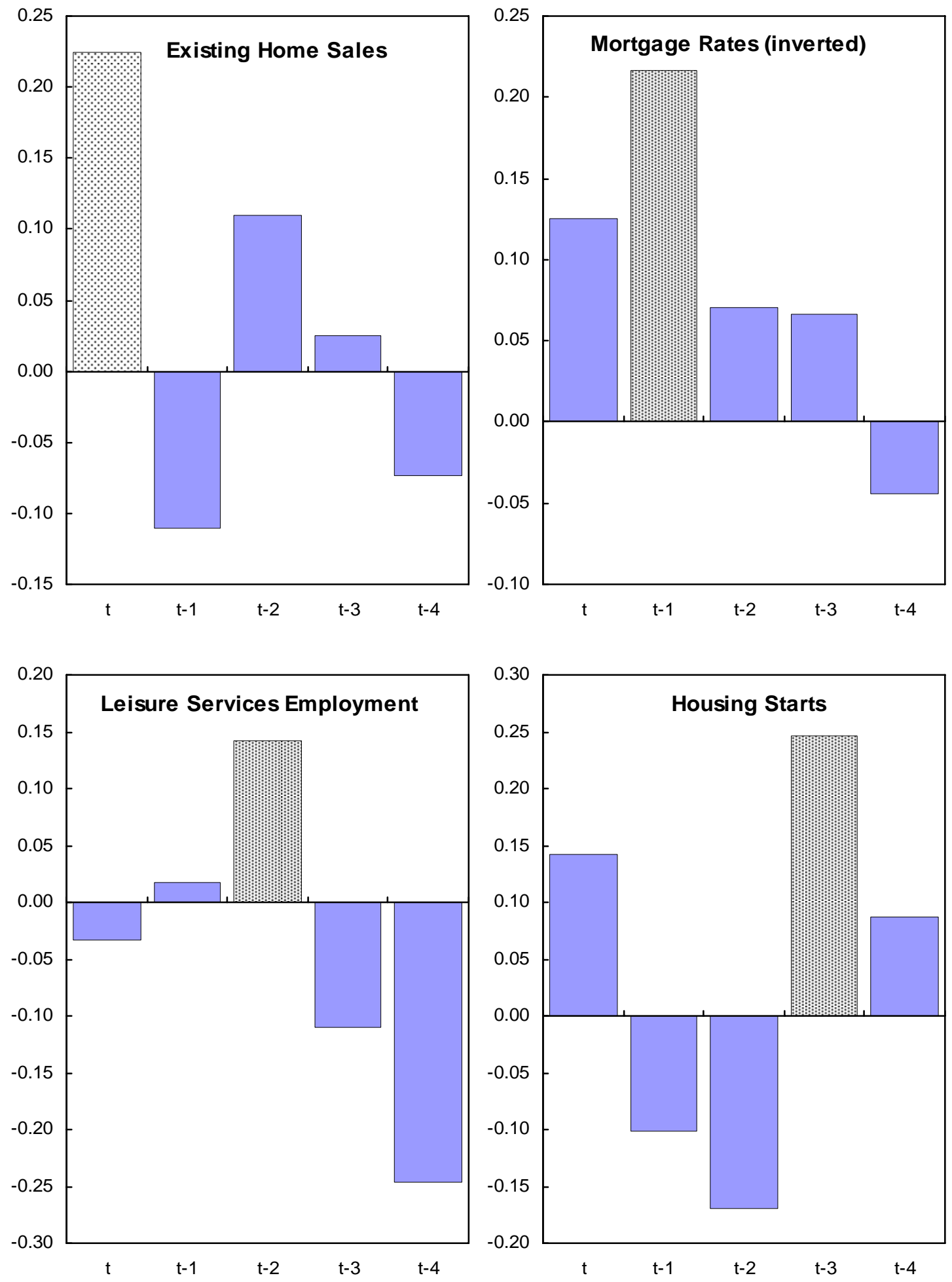

Source: Authors' calculations.

1 / The correlation coefficient is significant at the 5 percent level when higher than 0.28. 
Figure A7. Remittances Common Factor Model: Unobserved Components, 1990 Q1 - 2007 Q2 1/
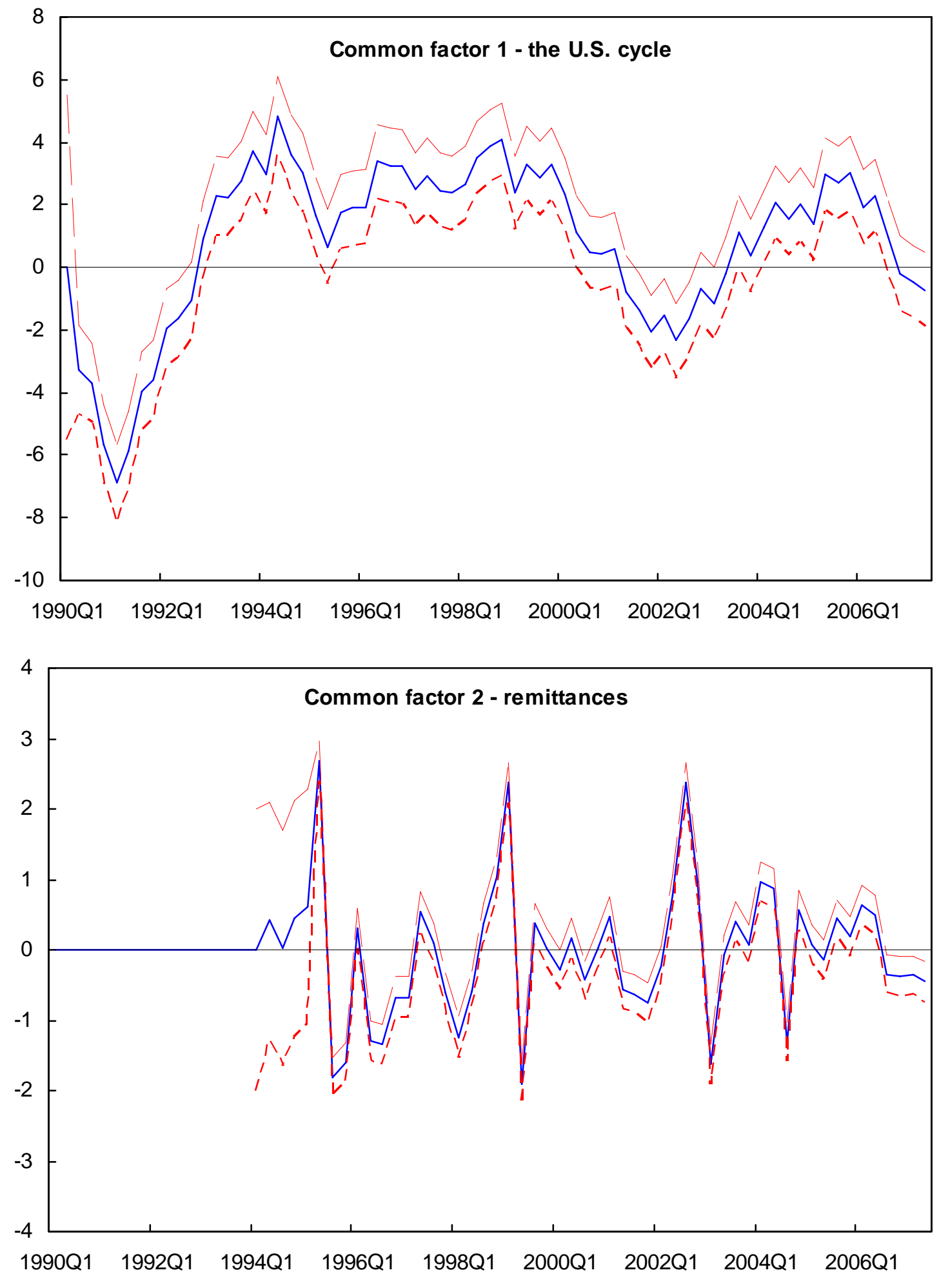

Source: Authors' calculations.

1/ Model using first-differences with 2-standard error bounds. 
Figure A8. Remittances Common Factor and Soverign Bond Yield Spreads

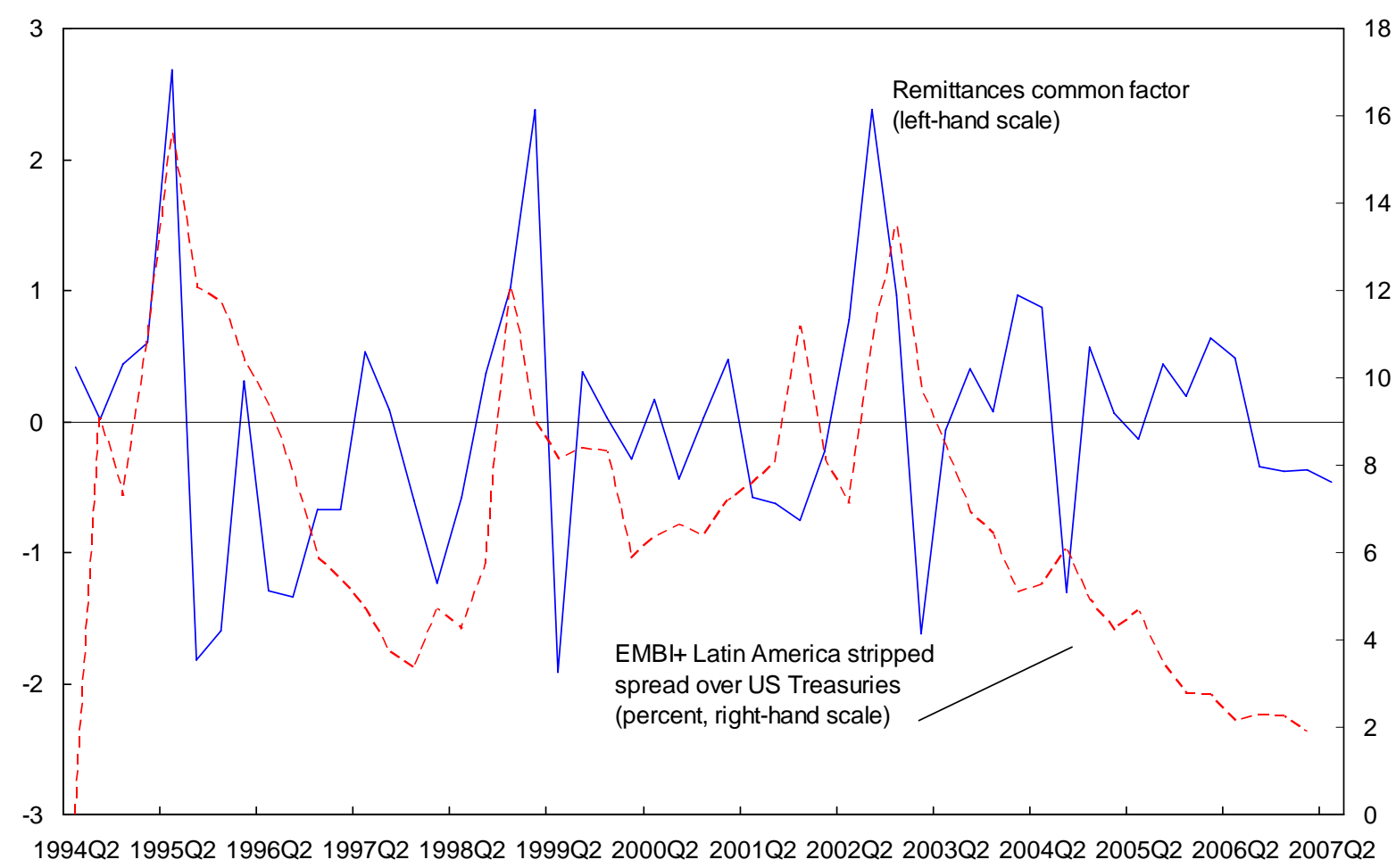

